\title{
Antimicrobial, Anthelmintic, and Antiviral Activity of Plants Traditionally Used for Treating Infectious Disease in the Similipal Biosphere Reserve, Odisha, India
}

\section{OPEN ACCESS}

Edited by:

Victor Kuete

Faculty of Science, University of Dschang, Cameroon

Reviewed by: Letizia Angiolella, Sapienza Università di Roma, Italy Mikhail Olugbemiro Nafiu, University of llorin, Nigeria

*Correspondence: Sujogya K. Panda sujogyapanda@gmail.com

Specialty section: This article was submitted to

Ethnopharmacology,

a section of the journal

Frontiers in Pharmacology

Received: 09 June 2017 Accepted: 05 September 2017 Published: 23 October 2017

Citation:

Panda SK, Padhi L, Leyssen P, Liu M, Neyts J and Luyten W (2017) Antimicrobial, Anthelmintic, and Antiviral Activity of Plants Traditionally Used for Treating Infectious Disease in the Similipal Biosphere Reserve,

Odisha, India.

Front. Pharmacol. 8:658. doi: 10.3389/fphar.2017.00658

\author{
Sujogya K. Panda ${ }^{1,2 *}$, Laxmipriya Padhi ${ }^{1}$, Pieter Leyssen ${ }^{3}$, Maoxuan Liu ${ }^{2}$, Johan Neyts ${ }^{3}$ \\ and Walter Luyten ${ }^{2}$
}

${ }^{1}$ Department of Zoology, North Orissa University, Baripada, India, ${ }^{2}$ Department of Biology, KU Leuven, Leuven, Belgium, ${ }^{3}$ Department of Microbiology and Immunology, Rega Institute for Medical Research, KU Leuven, Leuven, Belgium

In the present study, we tested in vitro different parts of 35 plants used by tribals of the Similipal Biosphere Reserve (SBR, Mayurbhanj district, India) for the management of infections. From each plant, three extracts were prepared with different solvents (water, ethanol, and acetone) and tested for antimicrobial (E. coli, S. aureus, C. albicans); anthelmintic (C. elegans); and antiviral (enterovirus 71) bioactivity. In total, 35 plant species belonging to 21 families were recorded from tribes of the SBR and periphery. Of the 35 plants, eight plants (23\%) showed broad-spectrum in vitro antimicrobial activity (inhibiting all three test strains), while 12 (34\%) exhibited narrow spectrum activity against individual pathogens (seven as anti-staphylococcal and five as anti-candidal). Plants such as Alangium salviifolium, Antidesma bunius, Bauhinia racemosa, Careya arborea, Caseria graveolens, Cleistanthus patulus, Colebrookea oppositifolia, Crotalaria pallida, Croton roxburghii, Holarrhena pubescens, Hypericum gaitii, Macaranga peltata, Protium serratum, Rubus ellipticus, and Suregada multiflora showed strong antibacterial effects, whilst Alstonia scholaris, Butea monosperma, C. arborea, C. pallida, Diospyros malbarica, Gmelina arborea, H. pubescens, M. peltata, $P$. serratum, Pterospermum acerifolium, R. ellipticus, and S. multiflora demonstrated strong antifungal activity. Plants such as A. salviifolium, A. bunius, Aporosa octandra, Barringtonia acutangula, C. graveolens, C. pallida, C. patulus, G. arborea, H. pubescens, H. gaitii, Lannea coromandelica, M. peltata, Melastoma malabathricum, Millettia extensa, Nyctanthes arbor-tristis, P. serratum, P. acerifolium, R. ellipticus, S. multiflora, Symplocos cochinchinensis, Ventilago maderaspatana, and Wrightia arborea inhibit survival of $C$. elegans and could be a potential source for anthelmintic activity. Additionally, plants such as A. bunius, C. graveolens, C. patulus, C. oppositifolia, H. gaitii, M. extensa, P. serratum, $R$. ellipticus, and $V$. maderaspatana showed anti-enteroviral activity. Most of the plants, whose traditional use as anti-infective agents by the tribals was well supported, show in vitro inhibitory activity against an enterovirus, bacteria (E. coil, S. aureus), a fungus (C. albicans), or a nematode (C. elegans).

Keywords: ethnopharmacology, traditional knowledge, antibacterial, antifungal, anthelmintic, antiviral, Similipal Biosphere Reserve 


\section{INTRODUCTION}

It has been estimated that less than 1-10\% of plant species of the world have been studied chemically and pharmacologically for their potential medicinal value (Verpoorte, 2000). For tropical forests that percentage is even much lower (Gurib-Fakim, 2005). Experts estimate that 137 species (plants or animals) are lost every single day $(50,000$ species in a year) due to rainforest deforestation (http://www.rain-tree.com/facts.htm\#.VVhhjRtS$\mathrm{zM})$. Plants species of tropical forests produce more chemical compounds for defense against pathogens and herbivores due to the high temperatures and scarcity of water during the summer, in addition to competing for space and light which force them to develop a robust means of energy and nutrient utilization along with adequate resources for secondary metabolite production (Fyhrquist, 2007). For these reasons, many tropical plant species contain secondary metabolites with potential medical utility (Wood-Sheldon et al., 1997).

The Similipal Biosphere Reserve (https://en.wikipedia.org/ wiki/Simlipal_National_Park\#Flora_and_fauna and Panda, 2014) is part of the UNESCO World Network of Biosphere Reserves since 2009, contains a fauna treasure trove of 1,076 plants (1,012 wild and 64 cultivated) from 168 families, including 60 species of pteridophytes, 92 species of orchids and two gymnosperms (Saxena and Brahmam, 1994-1996).

The use of medicinal plants for various ailments is a common practice among the tribal inhabitants of the SBR and is often passed orally from generation to generation. At the current stage, the younger generation of the SBR tribes shows little interest to inherit the traditional knowledge form their elders (Panda, 2014). So, a wealth of information now risks disappearing since it is often kept secret up to an old age by the initiated. Each time a traditional healer dies without passing his knowledge on to the next generation, the tribe and the world lose thousands of years of irreplaceable knowledge about medicinal plants.

Though traditional medicines have been recognized as a part of primary health care, there is a need to evaluate scientifically the crude extracts for clinical usefulness and toxicological risk. Although there are many reports available on antimicrobial properties of medicinal plants used by the tribes of Mayurbhanj, very few systematic surveys exist, and they mostly neglect the scientific validation of this traditional knowledge. Moreover, many surveys do not take full advantage of evidence for clinical efficacy in different diseases. The objective of the present paper is therefore to evaluate the antiviral, antibacterial, antifungal, and anthelmintic activities of medicinal plants used for treating

Abbreviations: ATCC, American Type Culture Collection, Manassas, Virginia, USA; CC, Cell controls; $\mathrm{CC}_{50-}, 50 \%$ Cytostatic/Cytotoxic Concentration; CPE, Cytopathic effect; DMSO, dimethyl sulphoxide; $\mathrm{EC}_{50}, 50 \%$ Effective Concentration; $\mathrm{EC}_{90}$, 90\% Effective Concentration; EV71, Enterovirus 71; FBS, Fetal bovine serum; LB, Luria-Bertani broth; MDR, Multi-drug resistant; MHA, Mueller-Hinton agar; $\mathrm{MIC}_{50}$, Minimum inhibitory concentration required to inhibit the growth by $50 \%$ of organisms; MTS, (3-[4,5,dimethylthiazol-2-yl]5-[3-carboxymethoxy-phenyl]-2-[4- sulfophenyl]-2H-tetrazolium, inner salt; NA, Nutrient agar; NGM, Nematode growth medium; OD, Optical density; RCF, Relative Centrifugal Force; SBR, Similipal Biosphere Reserve; SI, Selectivity index; SS, Selectivity Surface; TI, Therapeutic index; VC, Virus controls; YPD, Yeast extract peptone dextrose medium. infections by the tribes of the SBR (Mayurbhanj) in a systematic and consistent manner. The results can provide more scientific evidence supporting the clinical application of these plants, and can serve as a starting point for drug discovery. For each type of test, a common causative agent viz. Escherichia coli, Staphylococcus aureus (antibacterial-), Candida albicans (antifungal-), and enterovirus 71 (antiviral activity) was used as target organism, while for anthelmintic testing the model organism Caenorhabditis elegans was used.

\section{MATERIALS AND METHODS}

\section{Chemicals and Reagents}

Acetone (SZBE082SV) of analytical grade was purchased from Sigma-Aldrich Co. (USA). Absolute ethanol (E/0650DF/15) was purchased from Fischer Chemicals (UK). Sterile deionized water was produced by a water purification system (MilliQ Reagent Water System, MA, USA). Yeast extract and Bacto ${ }^{\mathrm{TM}}$ peptone were purchased from Lab M Ltd. (Lancashire, UK). Ammonium chloride, calcium chloride, cholesterol, ciprofloxacin hydrochloride, dextrose, dimethyl sulphoxide (DMSO, molecular biology grade), levamisole hydrochloride, magnesium sulfate, $( \pm)$-miconazole nitrate salt, rupintrivir, potassium dihydrogen phosphate, di-sodium hydrogen phosphate, sodium chloride, sodium hydroxide, and sucrose were all purchased from Sigma-Aldrich (MO, USA). MTS (3-[4,5 dimethylthiazol-2-yl]-5-[3-carboxymethyl-phenyl]2-[4-sulphophenyl]-2H-tetrazolium, inner salt), was purchased from Promega, Leiden, The Netherlands.

\section{Ethnobotanical Studies}

\section{Study Design and Sampling Procedure}

Field trips to the SBR were undertaken (2012-2013) for collecting medicinal plants. Geographic coordinates for each survey site were determined in the field with a global positioning system (GPS) receiver (Garmin Etrex, Olathe, Kansas, USA). Coordinates were recorded as latitude and longitude in decimal degrees. The ethnobotanical studies were performed according to the guidelines of Singh et al. (2013). Traditional knowledge holders (local tribal baidyas (https://en.wikipedia. org/wiki/Baidya) and elders) were included in the design of the study protocol and throughout its implementation. Most of these tribal baidyas are certified and government-recognized traditional knowledge holders (TKH) and belong to Aswin Kumar Vaidya Sangha, in the Mayurbhanj district, Odisha. A semi-structured questionnaire survey provided by SRISTI (Society for Research and Initiatives for Sustainable Technologies and Institutions; http://www.sristi.org/cms/) was employed to document the traditional knowledge. Data were collected in face-to-face interviews with translation where necessary. In total $14 \mathrm{TKH}$ were interviewed. All participants were male with average age of 45 . No minors were approached in the present survey. Personal interviews and group discussions with the TKH revealed specific information about the plants, which was further authenticated by crosschecking. Regarding common diseases, the respondents provided information about the frequent occurrence of infection (abscess, burn, wound, 
skin, eye and ear, sinusitis, diarrhea, dysentery), parasitic disease (different intestinal worms, malaria), bone fracture, gout, fever, jaundice, and snakebite.

\section{Ethical Issues}

To carry out research activities inside the Similipal Tiger Reserve (national park), permission was obtained from the Principal Chief Conservator of Forests (Odisha) and Field Director, Similipal Tiger Reserve-cum-Regional Chief Conservator of Forests, Baripada, Odisha. However, no permission was required for research activities in the villages near the transition zone of the SBR (http://www.moef.nic.in/division/biosphere-reserves). Ethnopharmacological studies of the type that we conducted fall under the authority of the Indian National Biodiversity Authority, an Autonomous and Statutory Body of the Ministry of Environment, Forest, and Climate Change, Government of India (http://nbaindia.org/link/304/1/1/home.html), and are governed by the Biological Diversity Act, 2002 (http://nbaindia. org/content/25/19/1/act.html).

Participating TKHs were contacted, and the purpose of the research project was explained to them before they gave written informed consent. Each participant of the study agreed to participate voluntarily. Participants were allowed to discontinue the interview at any time. The informed consent form that we used was developed by the National Innovation Foundation and Honey Bee Network and was obtained from the SRISTI website (http://www.sristi.org/cms/). After acceptance of the manuscript for publication, the data will be contributed to the Traditional Knowledge Digital Library (TKDL) of India (http://www.tkdl.res. in/tkdl/langdefault/common/Abouttkdl.asp?GL=Eng).

\section{Botanical Identification}

In the field work for each plant species, the following data were noted: local name, place, collection method, parts used, preparation methods, and medicinal value. The collected plant species were identified by professional taxonomists of North Orissa University (see acknowledgments) with the help of floras (Saxena and Brahmam, 1994-1996). None of them are endangered or protected species. Identification and voucher specimen deposition of these medicinal plants was done at the Department of Botany, North Orissa University, Baripada, and pictures of selected plants are shown in Figure 1. The information on these plants with their official taxonomic name (according to the plant list- http://www.theplantlist.org), local name, medicinal use, and used part(s), GPS coordinates, origin, and voucher numbers are shown in Table $\mathbf{1 .}$

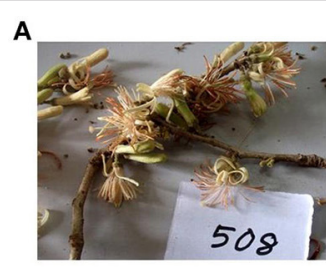

Alangium salviifolium

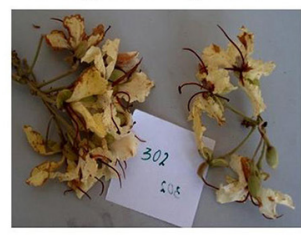

Bauhinia racemosa

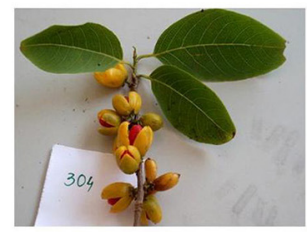

Casearia graveolens

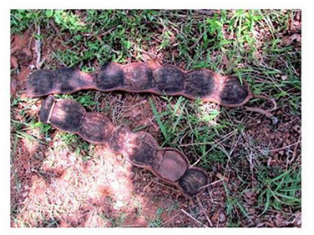

Entada rheedii

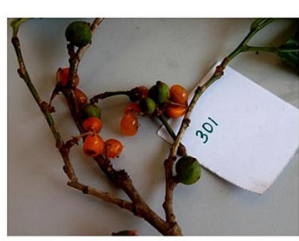

Aporosa octandra

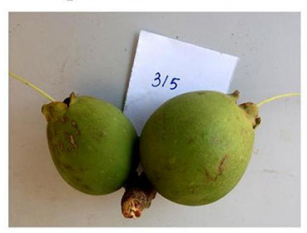

Careya arborea

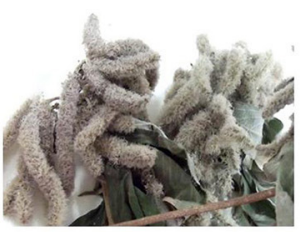

Colebrookea oppositifolia

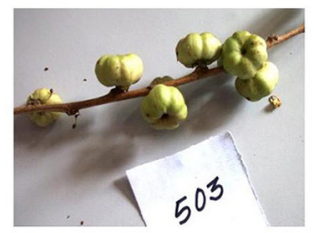

Glochidion velutinum

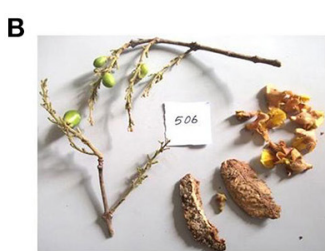

Gmelina arborea

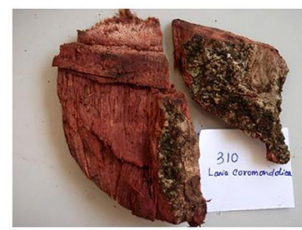

Lannea coromandelica

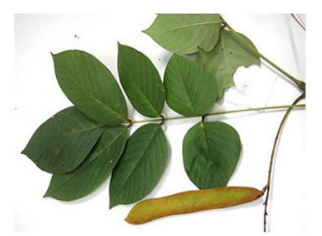

Millettia extensa

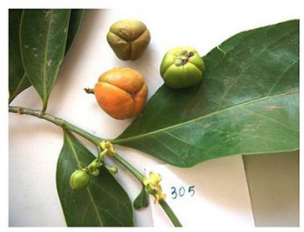

Suregada multiflora

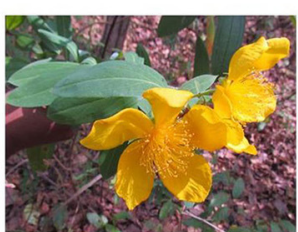

Hypericum gaitii

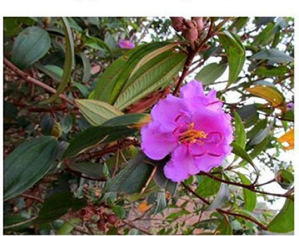

Melastoma malabathricum

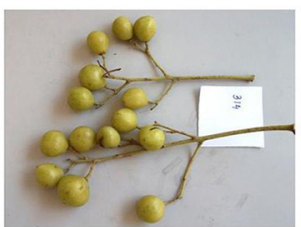

Protium serratum

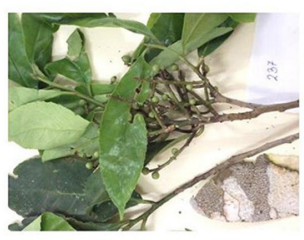

Symplocos cochinchinensis

FIGURE 1 | Photographs of selected plants from Similipal Biosphere Reserve. 
TABLE 1 | Ethnomedicinal uses of medicinal plants of SBR and Mayurbhanj district, India.

\begin{tabular}{|c|c|c|c|c|c|c|}
\hline Voucher No. & Taxonomic name & Local name & Family & Parts used & $\begin{array}{l}\text { GPS coordinates and } \\
\text { collection province }\end{array}$ & Medicinal uses \\
\hline NOU508/2013 & $\begin{array}{l}\text { Alangium salviifolium (L.f.) } \\
\text { Wangerin }\end{array}$ & $\begin{array}{l}\text { Baghanakhia/ } \\
\text { Ankula }\end{array}$ & Cornaceae & Leaf & $\begin{array}{l}21^{\circ} 53^{\prime} 30.9^{\prime \prime} \mathrm{N}, 86^{\circ} 23^{\prime} 55.0^{\prime \prime} \mathrm{E} ; \\
\text { Nawana }\end{array}$ & $\begin{array}{l}\text { Wound, infection due to } \\
\text { snakebite }\end{array}$ \\
\hline NOU100/2012 & Alstonia scholaris (L.) R. Br. & Chatiana & Apocyanaceae & Leaf & $\begin{array}{l}21^{\circ} 54^{\prime} 51.4^{\prime \prime} \mathrm{N}, 86^{\circ} 27^{\prime} 26.1^{\prime \prime} \mathrm{E} ; \\
\text { Lulung }\end{array}$ & Mouth infection, jaundice \\
\hline NOU105/2012 & $\begin{array}{l}\text { Anogeissus latifolia (Roxb. ex } \\
\text { DC.) Wall. ex Guill. \& Perr. }\end{array}$ & Dha/Dhaura & Combretaceae & Bark & $\begin{array}{l}21^{\circ} 54^{\prime} 51.4^{\prime \prime} \mathrm{N}, 86^{\circ} 27^{\prime} 26.1^{\prime \prime} \mathrm{E} ; \\
\text { Lulung }\end{array}$ & Diarrhea \\
\hline NOU312/2013 & Antidesma bunius (L.) Spreng. & Mutta & Phyllanthaceae & Bark, fruit & $\begin{array}{l}21^{\circ} 55^{\prime} 56.1^{\prime \prime} \mathrm{N}, 86^{\circ} 27^{\prime} 20.0^{\prime \prime} \mathrm{E} ; \\
\text { Machhakandana }\end{array}$ & $\begin{array}{l}\text { Infection (any), skin, } \\
\text { diarrhea }\end{array}$ \\
\hline NOU301/2013 & $\begin{array}{l}\text { Aporosa octandra } \\
\text { (Buch.-Ham. ex D. Don) } \\
\text { Vickery }\end{array}$ & Makania & Phyllanthaceae & Bark, leaf & $\begin{array}{l}21^{\circ} 53^{\prime} 30.9^{\prime \prime} \mathrm{N}, 86^{\circ} 23^{\prime} 55.0^{\prime \prime} \mathrm{E} ; \\
\text { Nawana }\end{array}$ & $\begin{array}{l}\text { Abscess, infection due to } \\
\text { bone fracture }\end{array}$ \\
\hline NOU213/2012 & $\begin{array}{l}\text { Barringtonia acutangula (L.) } \\
\text { Gaertn. }\end{array}$ & $\begin{array}{l}\text { Hinjala/ } \\
\text { Banasadina }\end{array}$ & Lecythidaceae & Leaf & $\begin{array}{l}21^{\circ} 56^{\prime} 51.2^{\prime \prime} \mathrm{N}, 86^{\circ} 33^{\prime} 19.3^{\prime \prime} \mathrm{E} \text {; } \\
\text { Sitakund }\end{array}$ & $\begin{array}{l}\text { Worm infection, skin } \\
\text { infection }\end{array}$ \\
\hline NOU302/2013 & Bauhinia racemosa Lam. & Anmata & Fabaceae & Leaf & $\begin{array}{l}21^{\circ} 46^{\prime} 22.5^{\prime \prime} \mathrm{N}, 86^{\circ} 31^{\prime} 00.6^{\prime \prime} \mathrm{E} \text {; } \\
\text { Debkund }\end{array}$ & $\begin{array}{l}\text { Infection (any), skin, } \\
\text { diarrhea }\end{array}$ \\
\hline NOU207/2012 & Buchanania lanzan Spreng. & Chara & Anacardiaceae & Bark & $\begin{array}{l}21^{\circ} 56^{\prime} 51.2^{\prime \prime} \mathrm{N}, 86^{\circ} 33^{\prime} 19.3^{\prime \prime} \mathrm{E} \\
\text { Sitakund }\end{array}$ & Diarrhea \\
\hline NOU290/2012 & $\begin{array}{l}\text { Butea monosperma (Lam.) } \\
\text { Taub. }\end{array}$ & Palasa & Leguminosae & Flower & $\begin{array}{l}21^{\circ} 58^{\prime} 32.2^{\prime \prime} \mathrm{N}, 86^{\circ} 36^{\prime} 35.2^{\prime \prime} \mathrm{E} ; \\
\text { Baldiha }\end{array}$ & Diarrhea, dysentery \\
\hline NOU315/2013 & Careya arborea Roxb. & Kumbhi & Lecythidaceae & Leaf & $\begin{array}{l}21^{\circ} 46^{\prime} 22.5^{\prime \prime} \mathrm{N}, 86^{\circ} 31^{\prime} 00.6^{\prime \prime} \mathrm{E} \text {; } \\
\text { Debkund }\end{array}$ & Skin infection \\
\hline NOU315/2013 & Careya arborea Roxb. & Kumbhi & Lecythidaceae & Bark & $\begin{array}{l}21^{\circ} 58^{\prime} 04.3^{\prime \prime} \mathrm{N}, 86^{\circ} 32^{\prime} 48.1^{\prime \prime} \mathrm{E} ; \\
\text { Champagad }\end{array}$ & Diarrhea, dysentery \\
\hline NOU304/2013 & Casearia graveolens Dalzell & Girchi & Salicaceae & Leaf & $\begin{array}{l}21^{\circ} 57^{\prime} 27.9^{\prime \prime} \mathrm{N}, 86^{\circ} 35^{\prime} 26.4^{\prime \prime} \mathrm{E} ; \\
\text { Lulung }\end{array}$ & Piscicide, skin infection \\
\hline NOU301/2013 & $\begin{array}{l}\text { Cleistanthus patulus (Roxb.) } \\
\text { Müll. Arg. }\end{array}$ & - & Phyllanthaceae & Leaf & $\begin{array}{l}21^{\circ} 46^{\prime} 22.5^{\prime \prime} \mathrm{N}, 86^{\circ} 31^{\prime} 00.6^{\prime \prime} \mathrm{E} \text {; } \\
\text { Debkund }\end{array}$ & $\begin{array}{l}\text { Infection (any), skin, } \\
\text { diarrhea }\end{array}$ \\
\hline NOU244/2012 & Colebrookea oppositifolia Sm. & Marang & Lamiaceae & Leaf & $\begin{array}{l}21^{\circ} 53^{\prime} 30.9^{\prime \prime} \mathrm{N}, 86^{\circ} 23^{\prime} 55.0^{\prime \prime} \mathrm{E} ; \\
\text { Nawana }\end{array}$ & $\begin{array}{l}\text { Sinusitis, malaria, } \\
\text { intestinal problems }\end{array}$ \\
\hline NOU215/2012 & Crotalaria pallida Aiton & - & Fabaceae & Fruit & $\begin{array}{l}21^{\circ} 46^{\prime} 22.5^{\prime \prime} \mathrm{N}, 86^{\circ} 31^{\prime} 00.6^{\prime \prime} \mathrm{E} \text {; } \\
\text { Debkund }\end{array}$ & Intoxication, antiparasitic \\
\hline NOU068/2012 & Croton roxburghii N.P. Balakr. & Putuli & Euphorbiaceae & Leaf & $\begin{array}{l}21^{\circ} 46^{\prime} 22.5^{\prime \prime} \mathrm{N}, 86^{\circ} 31^{\prime} 00.6^{\prime \prime} \mathrm{E} \text {; } \\
\text { Debkund }\end{array}$ & Diarrhea \\
\hline NOU062/2012 & Dillenia pentagyna Roxb. & Rai & Dilleniaceae & Leaf & $\begin{array}{l}21^{\circ} 56^{\prime} 51.2^{\prime \prime} \mathrm{N}, 86^{\circ} 33^{\prime} 19.3^{\prime \prime} \mathrm{E} \text {; } \\
\text { Sitakund }\end{array}$ & Diarrhea, dysentery \\
\hline NOU057/2012 & $\begin{array}{l}\text { Diospyros malbarica (Desr.) } \\
\text { Kostel. }\end{array}$ & Kalikendu & Ebenaceae & Leaf & $\begin{array}{l}21^{\circ} 56^{\prime} 51.2^{\prime \prime} \mathrm{N}, 86^{\circ} 33^{\prime} 19.3^{\prime \prime} \mathrm{E} \text {; } \\
\text { Sitakund }\end{array}$ & Skin infection, diarrhea \\
\hline NOU254/2012 & Enteda rheedii Spreng. & - & Leguminosae & Seed & $\begin{array}{l}21^{\circ} 53^{\prime} 30.9^{\prime \prime} \mathrm{N}, 86^{\circ} 23^{\prime} 55.0^{\prime \prime} \mathrm{E} ; \\
\text { Nawana }\end{array}$ & Eye infection \\
\hline NOU503/2013 & Glochidion velutinum Wight & - & Euphorbiaceae & Leaf & $\begin{array}{l}21^{\circ} 53^{\prime} 30.9^{\prime \prime} \mathrm{N}, 86^{\circ} 23^{\prime} 55.0^{\prime \prime} \mathrm{E} ; \\
\text { Nawana }\end{array}$ & $\begin{array}{l}\text { Infection due to bone } \\
\text { fracture, fever }\end{array}$ \\
\hline NOU506/2013 & Gmelina arborea Roxb. & Gambhari & Lamiaceae & Leaf & $\begin{array}{l}21^{\circ} 58^{\prime} 04.3^{\prime \prime} \mathrm{N}, 86^{\circ} 32^{\prime} 48.1^{\prime \prime} \mathrm{E} ; \\
\text { Champagad }\end{array}$ & $\begin{array}{l}\text { Infection (any), skin, } \\
\text { malaria }\end{array}$ \\
\hline NOU059/2012 & $\begin{array}{l}\text { Holarrhena pubescens } \\
\text { (Buch.-Ham.) Wall. ex G. Don }\end{array}$ & Kuruchi & Apocynaceae & Bark & $\begin{array}{l}21^{\circ} 54^{\prime} 51.4^{\prime \prime} \mathrm{N}, 86^{\circ} 27^{\prime} 26.1^{\prime \prime} \mathrm{E} ; \\
\text { Lulung }\end{array}$ & $\begin{array}{l}\text { Malaria, diarrhea, } \\
\text { dysentery }\end{array}$ \\
\hline NOU059/2012 & $\begin{array}{l}\text { Holarrhena pubescens } \\
\text { (Buch.-Ham.) Wall. ex G. Don }\end{array}$ & Kuruchi & Apocynaceae & Leaf & $\begin{array}{l}21^{\circ} 54^{\prime} 51.4^{\prime \prime} \mathrm{N}, 86^{\circ} 27^{\prime} 26.1^{\prime \prime} \mathrm{E} \\
\text { Lulung }\end{array}$ & Skin infection, jaundice \\
\hline NOU228/2012 & Hypericum gaitii Haines & - & Hypericaceae & Leaf & $\begin{array}{l}21^{\circ} 47^{\prime} 27.2^{\prime \prime} \mathrm{N}, 86^{\circ} 24^{\prime} 02.35^{\prime \prime} \mathrm{E} ; \\
\text { Nawana }\end{array}$ & $\begin{array}{l}\text { Skin infection, sore throat, } \\
\text { fever }\end{array}$ \\
\hline NOU310/2013 & $\begin{array}{l}\text { Lannea coromandelica } \\
\text { (Houtt.) Merr. }\end{array}$ & Jia & Anacardiaceae & Bark & $\begin{array}{l}21^{\circ} 56^{\prime} 51.2^{\prime \prime} \mathrm{N}, 86^{\circ} 33^{\prime} 19.3^{\prime \prime} \mathrm{E} ; \\
\text { Sitakund }\end{array}$ & $\begin{array}{l}\text { Worm infection, skin } \\
\text { infection }\end{array}$ \\
\hline NOU301/2013 & $\begin{array}{l}\text { Macaranga peltata (Roxb.) } \\
\text { Müll. Arg. }\end{array}$ & Manda & Euphorbiaceae & Leaf & $\begin{array}{l}21^{\circ} 55^{\prime} 56.1^{\prime \prime} \mathrm{N}, 86^{\circ} 27^{\prime} 20.0^{\prime \prime} \mathrm{E} ; \\
\text { Machhakandana }\end{array}$ & Skin infection \\
\hline NOU232/2012 & Melastoma malabathricum L. & Korali & Melastomataceae & Leaf & $\begin{array}{l}21^{\circ} 53^{\prime} 30.9^{\prime \prime} \mathrm{N}, 86^{\circ} 23^{\prime} 55.0^{\prime \prime} \mathrm{E} ; \\
\text { Nawana }\end{array}$ & $\begin{array}{l}\text { Infection (any), skin, } \\
\text { diarrhea }\end{array}$ \\
\hline
\end{tabular}


TABLE 1 | Continued

\begin{tabular}{|c|c|c|c|c|c|c|}
\hline Voucher No. & Taxonomic name & Local name & Family & Parts used & $\begin{array}{l}\text { GPS coordinates and } \\
\text { collection province }\end{array}$ & Medicinal uses \\
\hline NOU414/2013 & $\begin{array}{l}\text { Millettia extensa (Benth.) } \\
\text { Baker }\end{array}$ & Gora & Leguminosae & Leaf & $\begin{array}{l}21^{\circ} 47^{\prime} 27.2^{\prime \prime} \mathrm{N}, 86^{\circ} 24^{\prime} 02.35^{\prime \prime} \mathrm{E} ; \\
\text { Nawana }\end{array}$ & Skin infection, cough \\
\hline NOU208/2012 & Mimosa rubicaulis Lam. & Chur & Leguminosae & Leaf & $\begin{array}{l}21^{\circ} 57^{\prime} 27.9^{\prime \prime} \mathrm{N}, 86^{\circ} 35^{\prime} 26.4^{\prime \prime} \mathrm{E} ; \\
\text { Lulung }\end{array}$ & $\begin{array}{l}\text { Burns, wound infections } \\
\text { (any) }\end{array}$ \\
\hline NOU542/2013 & Nyctanthes arbor-tristis L. & $\begin{array}{l}\text { Haragoura/ } \\
\text { Gangasiuli }\end{array}$ & Oleaceae & Leaf & $\begin{array}{l}21^{\circ} 58^{\prime} 32.2^{\prime \prime} \mathrm{N}, 86^{\circ} 36^{\prime} 35.2^{\prime \prime} \mathrm{E} \\
\text { Baldiha }\end{array}$ & $\begin{array}{l}\text { Infection (any), skin, } \\
\text { diarrhea, malaria, jaundice }\end{array}$ \\
\hline NOU314/2013 & $\begin{array}{l}\text { Protium serratum (Wall. ex } \\
\text { Colebr.) Engl. }\end{array}$ & Rajmoi & Burseraceae & Fruit & $\begin{array}{l}21^{\circ} 53^{\prime} 30.9^{\prime \prime} \mathrm{N}, 86^{\circ} 23^{\prime} 55.0^{\prime \prime} \mathrm{E} \\
\text { Nawana }\end{array}$ & Tuberculosis, cough \\
\hline NOU103/2012 & $\begin{array}{l}\text { Pterospermum acerifolium (L.) } \\
\text { Willd. }\end{array}$ & Muchkunda & Sterculiaceae & Bark & $\begin{array}{l}21^{\circ} 58^{\prime} 04.3^{\prime \prime} \mathrm{N}, 86^{\circ} 32^{\prime} 48.1^{\prime \prime} \mathrm{E} ; \\
\text { Champagad }\end{array}$ & Diarrhea, dysentery \\
\hline NOU103/2012 & $\begin{array}{l}\text { Pterospermum acerifolium (L.) } \\
\text { Willd. }\end{array}$ & Muchkunda & Sterculiaceae & Flower & $\begin{array}{l}21^{\circ} 58^{\prime} 04.3^{\prime \prime} \mathrm{N}, 86^{\circ} 32^{\prime} 48.1^{\prime \prime} \mathrm{E} ; \\
\text { Champagad }\end{array}$ & Diarrhea \\
\hline NOU103/2012 & Rubus ellipticus Sam. & Machaokodi & Rosaceae & Leaf & $\begin{array}{l}21^{\circ} 47^{\prime} 27.2^{\prime \prime} \mathrm{N}, 86^{\circ} 24^{\prime} 02.35^{\prime \prime} \mathrm{E} ; \\
\text { Nawana }\end{array}$ & Diarrhea, malaria \\
\hline NOU305/2013 & $\begin{array}{l}\text { Suregada multiflora (A. Juss.) } \\
\text { Baill. }\end{array}$ & Khakra & Euphorbiaceae & Leaf & $\begin{array}{l}21^{\circ} 46^{\prime} 22.5^{\prime \prime} \mathrm{N}, 86^{\circ} 31^{\prime} 00.6^{\prime \prime} \mathrm{E} \text {; } \\
\text { Debkund }\end{array}$ & Skin \\
\hline NOU305/2013 & $\begin{array}{l}\text { Suregada multiflora (A. Juss.) } \\
\text { Baill. }\end{array}$ & Khakra & Euphorbiaceae & Bark, seed & $\begin{array}{l}21^{\circ} 46^{\prime} 22.5^{\prime \prime} \mathrm{N}, 86^{\circ} 31^{\prime} 00.6^{\prime \prime} \mathrm{E} \text {; } \\
\text { Debkund }\end{array}$ & Diarrhea, dysentery \\
\hline NOU103/2012 & $\begin{array}{l}\text { Symplocos cochinchinensis } \\
\text { (Lour.) S. }\end{array}$ & - & Symplococeae & Leaf & $\begin{array}{l}21^{\circ} 53^{\prime} 30.9^{\prime \prime} \mathrm{N}, 86^{\circ} 23^{\prime} 55.0^{\prime \prime} \mathrm{E} ; \\
\text { Nawana }\end{array}$ & Skin \\
\hline NOU426/2013 & $\begin{array}{l}\text { Ventilago maderaspatana } \\
\text { Gaertn. }\end{array}$ & Raktapichula & Rhamnaceae & Bark, leaf & $\begin{array}{l}21^{\circ} 53^{\prime} 30.9^{\prime \prime} \mathrm{N}, 86^{\circ} 23^{\prime} 55.0^{\prime \prime} \mathrm{E} ; \\
\text { Nawana }\end{array}$ & $\begin{array}{l}\text { Gout, bone fracture, ear, } \\
\text { eye infection }\end{array}$ \\
\hline NOU306/2013 & $\begin{array}{l}\text { Wrightia arborea (Dennst.) } \\
\text { Mabb. }\end{array}$ & Pita karua & Apocynaceae & Leaf & $\begin{array}{l}21^{\circ} 46^{\prime} 22.5^{\prime \prime} \mathrm{N}, 86^{\circ} 31^{\prime} 00.6^{\prime \prime} \mathrm{E} ; \\
\text { Debkund }\end{array}$ & $\begin{array}{l}\text { Diarrhea, skin infection, } \\
\text { asthma }\end{array}$ \\
\hline
\end{tabular}

\section{Preparation of the Extract}

Bark, flowers, fruit, leaves, or roots of plants were collected separately during field trips to different places of the SBR. After collection, the healthy leaves were dried at ambient temperature in the absence of sunlight for 7 days to maintain their green color and volatile oils, if present. Other parts such as bark, root, flower, fruits, were dried in an oven (Labotech Solutions, India) at $50^{\circ} \mathrm{C}$ for 4 days. All the materials were completely dried to prevent growth of fungi, molds, bacteria, or other microorganisms (Panda et al., 2016). The dried raw botanical material was ground to a fine powder and stored in PearlPet plastic jars, $600 \mathrm{gm}$. One gram of powder was transferred into each of three $15 \mathrm{~mL}$ sterile polypropylene tubes with screwcaps, and $10 \mathrm{~mL}$ of sterile water, absolute ethanol, or acetone were added, respectively. Extraction was performed at ambient temperature with the aid of repeated vortexing and sonication $(4 \times 15 \mathrm{~min}$ over a $24 \mathrm{~h}$ period $)$ in a sonicator water bath (Branson, USA). After 1 day, the tubes were centrifuged for $10 \mathrm{~min}$ at $2000 \mathrm{RCF}$ (Hettich Rotanta 46R, C4810, Germany) and the supernatant transferred in $1 \mathrm{~mL}$ aliquots to 1.5 $\mathrm{mL}$ Eppendorf tubes. After evaporation of the solvent in a Savant SpeedVac Concentrator (SVC 200H, Stratech Scientific, London, UK), the dried residue of $1 \mathrm{~mL}$ extract was re-dissolved in $200 \mu \mathrm{L}$ water (for the aqueous extract) or $200 \mu \mathrm{L}$ DMSO for the ethanol and acetone extracts. For the antiviral assay, $1 \mathrm{~mL}$ of each extract was transferred to a special tube (2D barcoded $2 \mathrm{~mL}$ storage tube, Thermo Scientific* Abgene) and the solvent was evaporated as described above. The dry residue was dissolved in DMSO to a final stock concentration of $10 \mathrm{mg} / \mathrm{mL}$. The samples were stored at $4^{\circ} \mathrm{C}$ until further testing.

\section{Antimicrobial Test Microbial Strains}

Bacterial strains E. coli (DH10B), S. aureus ATCC 65385 (Rosenbach), and fungal strain C. albicans (SC5314) (American Type Culture Collection, Manassas, Virginia, USA) (Fonzi and Irwin, 1993) were used for the antibacterial and antifungal test, respectively. For bacteria, colonies were inoculated on MuellerHinton $(\mathrm{MH})$ agar plates, while for Candida, colonies were inoculated on YPD agar, and after overnight growth both plate types were sealed with parafilm and stored in a cold room $\left(4^{\circ} \mathrm{C}\right)$.

\section{Preparation of Pre-culture}

A single colony of $C$. albicans, E. coli, or $S$. aureus was inoculated from an agar plate in $5 \mathrm{~mL}$ of YPD medium (1\% yeast extract, $2 \%$ peptone, and $2 \%$ dextrose) for Candida, or MH medium ( $0.2 \%$ beef extract, $1.75 \%$ casamino acids, and $0.015 \%$ soluble starch) for bacteria, in separate reaction tubes under aseptic conditions. The reaction tubes were incubated overnight while shaking at 200 rpm at $37^{\circ} \mathrm{C}$.

\section{Antibacterial Activity Test (Microdilution Broth) Protocol}

Ten $\mu \mathrm{L}$ of the test sample was transferred into the wells of a 96well plate, as well as the positive control (ciprofloxacin, stock $100 \mu \mathrm{g} / \mathrm{mL}$ ) and blank (solvent) controls (DMSO and water). Each well of a microdilution plate was than inoculated with $190 \mu \mathrm{L}$ of the diluted standardized inoculum (OD $=0.003$ at $620 \mathrm{~nm}$ ). Control wells were prepared with $190 \mu \mathrm{L} \mathrm{MH}$ broth and $10 \mu \mathrm{L}$ extract to correct of any absorption due to extract 
components. The microdilution plates were placed in a shakerincubator at $37^{\circ} \mathrm{C}$ for $18 \mathrm{~h}$, and then read on a Mithras LB 940 Multimode Microplate Reader (Berthold Technologies GmbH \& Co. KG, Bad Wildbad, Germany) at $620 \mathrm{~nm}$ with a lamp energy of 13,000 using the MikroWin 2000 software package. The OD was measured at a wavelength of $620 \mathrm{~nm}$ and wells with a plant extract were corrected for the absorption contributed by the extract. Tests were typically carried out in duplicate. The relative inhibition (\%) of the test sample was calculated by dividing the OD value of the test sample minus that of the non-inoculated extract control by the average OD of the solvent control, and multiplying by 100 .

\section{Antifungal Test}

Antifungal activity was tested against C. albicans in a similar way as for bacteria. Instead of MH broth, YPD broth was used with a smaller quantity of plant extract (to keep the final DMSO concentration below 2\%). For antifungal activity, each well of a microdilution plate was inoculated with $196 \mu \mathrm{L}$ of the diluted yeast suspension and $4 \mu \mathrm{L}$ of the test solution was added. Control wells were prepared with $196 \mu \mathrm{L}$ YPD broth and $4 \mu \mathrm{L}$ extract to correct for any absorption due to extract components, or $4 \mu \mathrm{L}$ of DMSO or MilliQ (solvent control), or the antifungal miconazole $(200 \mu \mathrm{g} / \mathrm{mL})$ in DMSO (positive control).

\section{Determination of Minimum Inhibitory Concentration $\left(\mathrm{MIC}_{50}\right)$}

The $\mathrm{MIC}_{50}$ was determined using the 96-well microdilution method as described earlier in section Antibacterial Activity Test (Microdilution Broth) Protocol. The dry weight of each extract was determined on an analytical balance (Sartorius ME235P, Germany). The dry residue was dissolved in $200 \mu \mathrm{L}$ DMSO (sterile water for aqueous extracts), and a 2-fold serial dilution (up to 32-fold) was prepared in a 96-well conical bottom (V) microplate. Data from dose-response experiments were represented as the percentage of inhibition, and analyzed with Prism $^{\mathrm{TM}}$ (GraphPad Prism 5.0 Software Inc., San Diego, CA). The $\mathrm{MIC}_{50}$ for each growth condition was calculated by fitting the data to a non-linear least-squares sigmoid regression curve.

\section{Anthelmintic Activity}

\section{Culture, Maintenance, and Synchronization of Caenorhabditis elegans (C. elegans) Strains}

The $\mathrm{N}_{2}$ wild-type $C$. elegans strain was grown on Nematode Growth Medium (NGM) in Petri dishes containing a lawn of the bacterium E. coli OP50 (Brenner, 1974). Synchronized populations were obtained by a modified alkaline bleaching method (Lenaerts et al., 2008). Briefly, worm culture plates with eggs and egg-laying adults were washed with M9 buffer and incubated with freshly prepared bleaching solution, followed by three washes with M9. Then, $3.5 \mathrm{~mL}$ of worm suspension was added to $1.5 \mathrm{~mL}$ of alkaline hypochlorite solution ( $1 \mathrm{~mL}$ of bleach and $0.5 \mathrm{~mL}$ of $5 \mathrm{M} \mathrm{NaOH}$ ). The suspension was shaken for 5 $\mathrm{min}$, and $5.0 \mathrm{~mL}$ of a sucrose solution $(60 \% \mathrm{w} / \mathrm{v})$ was added. Then, $1 \mathrm{~mL}$ of $\mathrm{M} 9$ buffer was gently added to the mixture, followed by centrifugation at 290 RCF (Hettich Rotanta 46R, C4810, Germany) for $3 \mathrm{~min}$. After centrifugation, the eggs were collected and washed five times with M9 buffer were. Eggs in M9 were kept on a rotator at $20^{\circ} \mathrm{C}$ overnight in the absence of light to hatch into L1 larvae (L1s). After $24 \mathrm{~h}$ of incubation, L1s were transferred onto a fresh NGM plate seeded with an E. coli OP50 lawn and grown at $20^{\circ} \mathrm{C}$ (L2s). "L4" larvae were isolated from those plates after $48 \mathrm{~h}$ were washed four times with M9 buffer before being used for assays with plant extracts.

\section{Anthelmintic Assay}

The anthelmintic assay was carried out in a 96-well microplate (flat-bottom, TPP Techno Plastic Products AG, Switzerland). Synchronized C. elegans $(15 \mu \mathrm{L}, \sim 45 \mathrm{~L} 4$ larvae) were added to each well of a 96-well microplate containing $184 \mu \mathrm{L}$ of $E$. coli OP50 culture $(\mathrm{OD}=0.5$ at $620 \mathrm{~nm})$. Subsequently, $1 \mu \mathrm{L}$ of plant extract was added to each well; DMSO $(1 \mu \mathrm{L})$ was used in a separate well as a solvent control. After mixing, the 96well microplate was placed into a WMicroTracker (Phylumtech, Argentina) apparatus and incubated for $16 \mathrm{~h}$ at $20^{\circ} \mathrm{C}$. The movement of worms in each well was measured every 30 min and recorded by the WMicroTracker. The percentage of the average movement over $16 \mathrm{~h}$ of test samples with extract compared to the DMSO control, was used to estimate the relative anthelmintic activity. Levamisole (final concentration $50 \mu \mathrm{M}$ ) was systematically used as a positive control.

\section{Antiviral Test}

The EV71 BrCr laboratory-adapted strain was used at a low multiplicity of infection (MOI) in a standardized antiviral assay as described earlier (Martínez-Gualda et al., 2017). Briefly, a serial dilution of the extract(s) was prepared in assay medium that was added to an empty microtiter 96-well plate, after which the virus inoculum was added, followed by a suspension of freshly harvested rhabdosarcoma $(\mathrm{RD})$ cells $\left(2 \times 10^{4}\right.$ cells/well $)$. While the cells were settling to the bottom, the virus was allowed to infect them in the presence of extract. The assay plates were incubated at $37^{\circ} \mathrm{C}, 5 \% \mathrm{CO}_{2}$ with virus inoculum and compounds until full virus-induced cell death was observed in the untreated, infected controls (3-4 days post-infection). Subsequently, the antiviral effect was quantified using a colorimetric readout with 3- (4,5-dimethylthiazol-2-yl)-5-(3-carboxymethoxyphenyl)2-(4-sulfophenyl)-2H-tetrazolium/phenazine methosulfate (MTS/PMS method) and the concentration of compound at which $50 \%$ inhibition of virus-induced cell death would be observed $\left(\mathrm{EC}_{50}\right)$ was calculated from the antiviral dose-response curves. A similar assay setup was used to determine the adverse effect of an extract or test compound on uninfected, treated cells for calculation of the $\mathrm{CC}_{50}$ (concentration of sample that reduces overall cell health by $50 \%$ as determined by the MTS/PMS method). The final, maximal DMSO concentration that was reached in the assay wells with the highest sample input (1\%) was well-tolerated by the cells. Rupintrivir was used as a positive control (Martínez-Gualda et al., 2017). In addition, the selectivity index (SI) was calculated as the ratio of the $\mathrm{CC}_{50}$ for cell growth to the $\mathrm{EC}_{50}$. The Selectivity Surface-SS, was determined from plots (CPE and CC curve) and the Therapeutic Index-TI was calculated as (SS*10logSI) (Supplementary Material). 


\section{RESULTS}

\section{Ethnomedicinal Documentation}

The ethnomedicinal uses of 35 plant species belonging to 21 families were recorded from tribes of the SBR and periphery (Table 1). The information on these plants with botanical names (arranged alphabetically), voucher number, local name, taxonomic family, used plant part, origin, and medicinal uses is shown in Table 1. Most of the reported medicinal uses pertained to the treatment of infections such as skin infection (19), diarrhea (17), dysentery (defined as bloody diarrhea) (6), malaria (4), jaundice (3), parasitic (3), wound (3) or other infections of e.g., eye, ear, mouth, or throat, or for bone fractures, snake bites

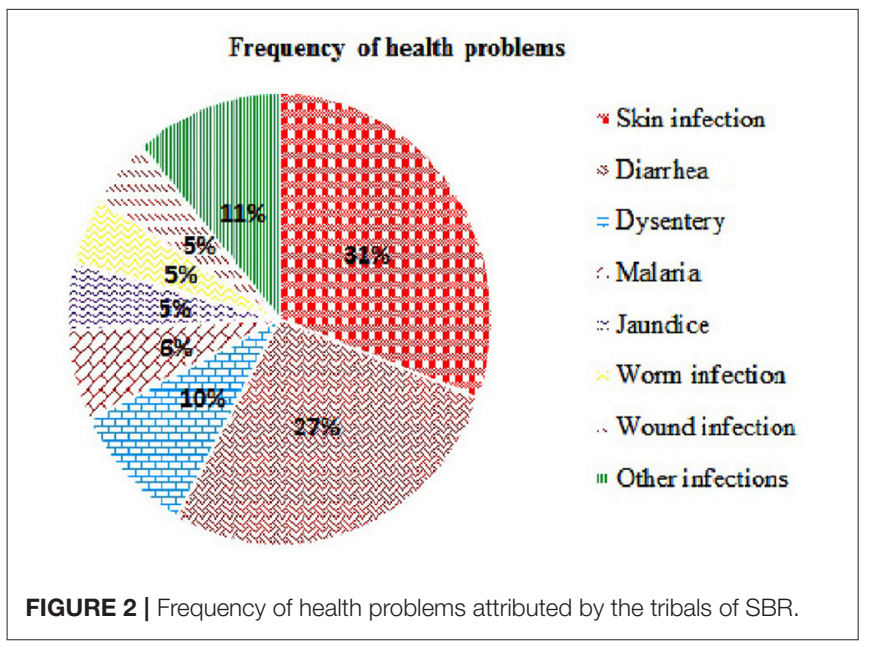

etc. (7) (Figure 2). According to the number of given uses, the most represented families are Euphorbiaceae (5), Apocynaceae (4), Leguminosae (4), Lecythidaceae (3), and Phyllanthaceae (3) (Figure 3).

\section{Antimicrobial Activity}

Antibacterial activity in microdilution broth assays with crude extracts (aqueous, acetone, and ethanol) of different plant parts of different species is presented in Table 2 (percentages of inhibition surpassing 50 are underlined). In total, 285 extracts were tested, of which 86 extract showed high activity while 122 extracts did not show activity (Figure 3). Additionally, 38 extracts had medium-while 39 extracts had low antimicrobial activity (Figure 3). Most activity was detected in ethanol extracts, followed by acetone and aqueous extracts. Of the 35 plants screened, 17 showed activities in at least one extract against $E$. coli, 34 against $S$. aureus, and 14 against C. albicans (Figures 4, 5). Among the tested plants, six showed activity against E. coli in the acetone extracts, 10 in the ethanol extracts, and 11 in water extracts. In a few cases, negative values were calculated for the $\%$ inhibition. Taken at face value, this could mean that the extract enhanced (rather than inhibited) bacterial growth. This cannot be excluded, but more likely the negative values are due to a combination of experimental variation and an overcorrection for colored compounds in the control samples without bacteria. This may occur when bacteria metabolize some of the colored components in the extract.

Plants that showed more than $75 \%$ inhibition with the broth dilution method were further tested by 2 -fold serial dilution to evaluate their MIC. The $\mathrm{MIC}_{50}$ of the selected extracts against $E$.

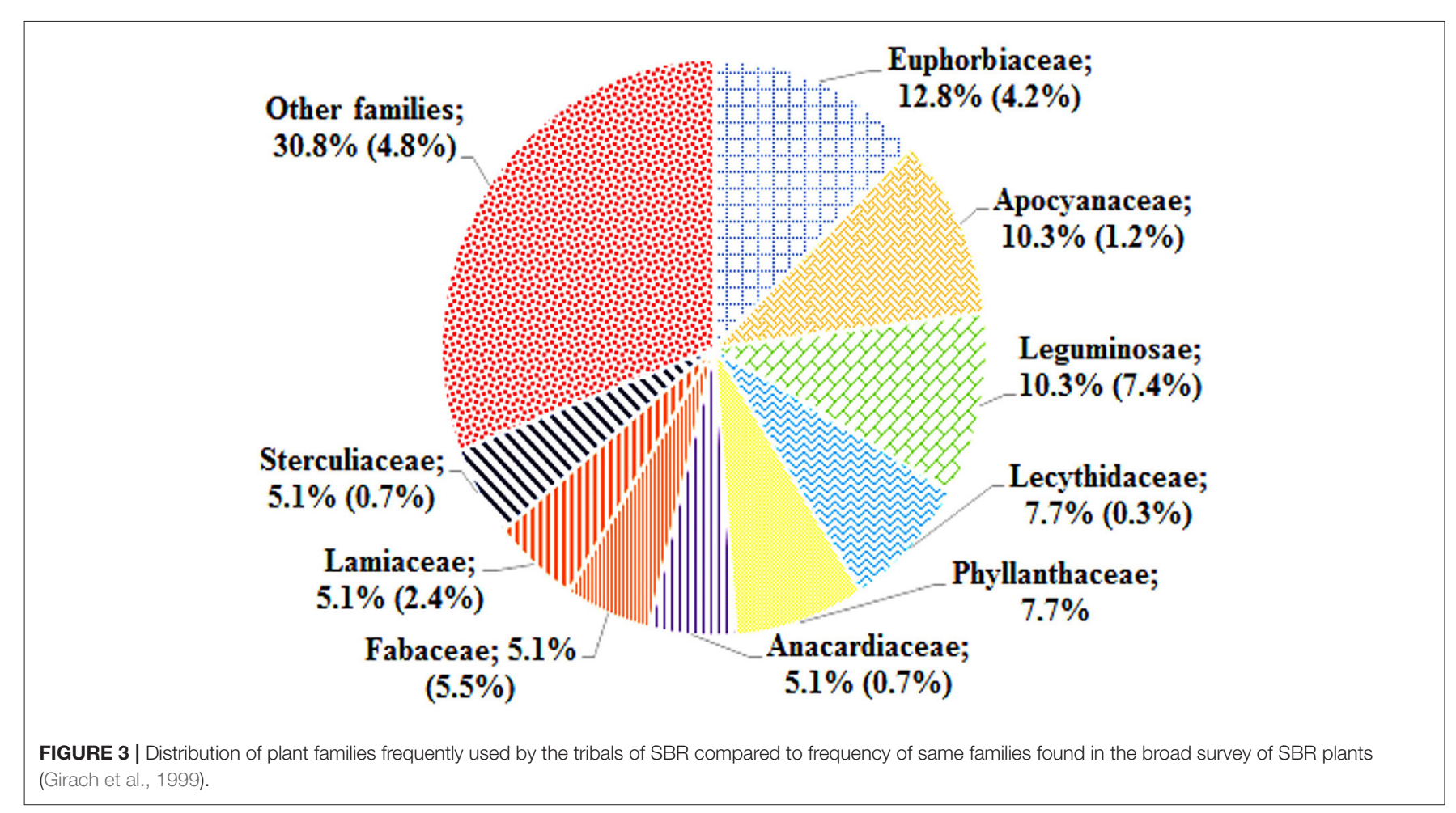


TABLE 2 | Antimicrobial activity of selected extracts of plants collected from SBR, India (growth inhibition in \% compared to the solvent, OD at $620 \mathrm{~nm}$ ).

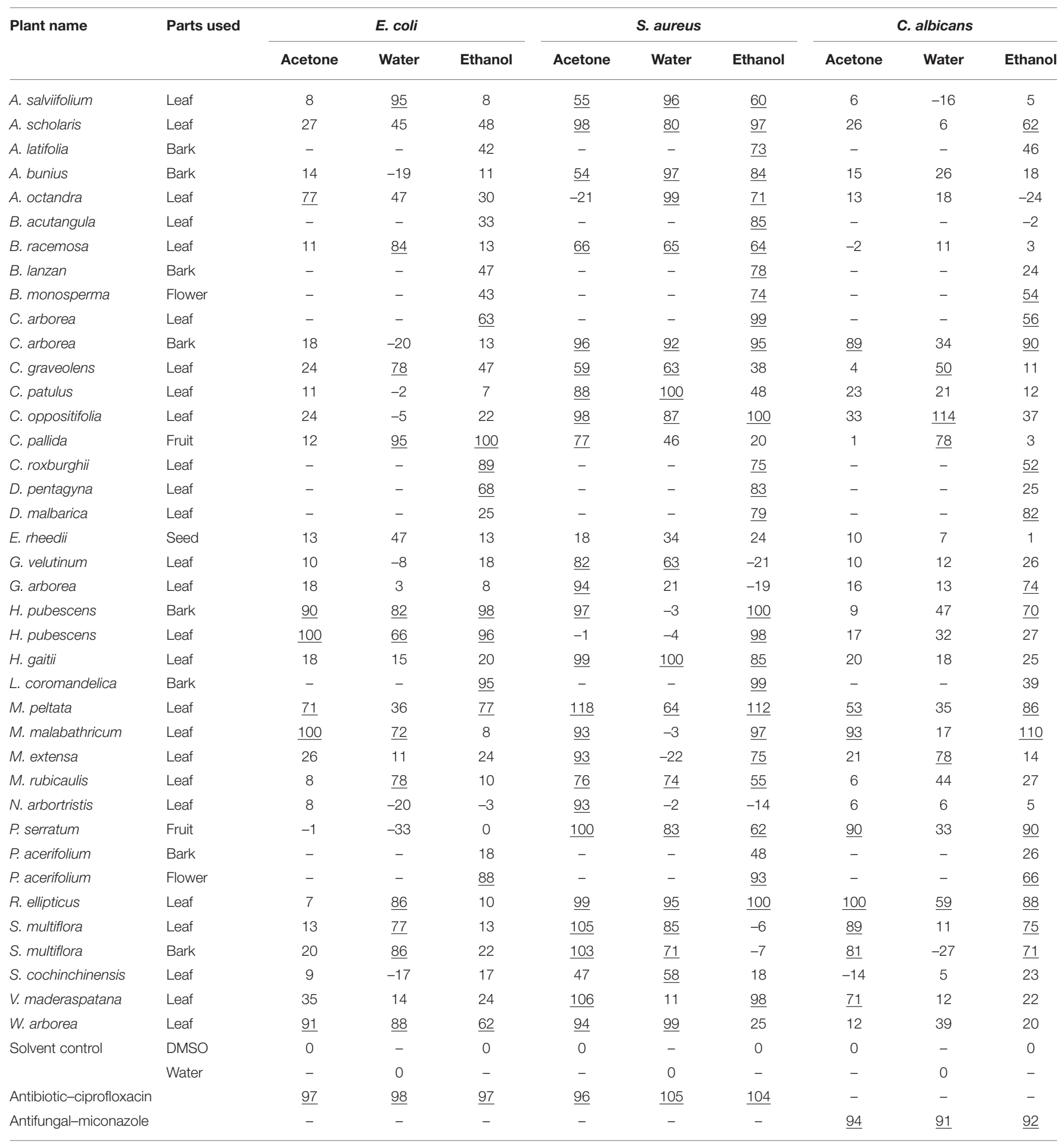

(-) Data absent, \% growth inhibition data were rounded to the nearest integer. Underlined values represent above 50 inhibition.

coli, S. aureus, and C. albicans are summarized in Table 3. Most of the test extracts inhibited growth at less than $1,000 \mu \mathrm{g} / \mathrm{mL}$. The $\mathrm{MIC}_{50}$ value range from $(100-1,400 \mu \mathrm{g} / \mathrm{mL}),(50-1,370 \mu \mathrm{g} / \mathrm{mL})$, and $(150-780 \mu \mathrm{g} / \mathrm{mL})$ against E. coli, S. aureus, and C. albicans, respectively.
Except for Entada rheedii, all tested plants showed inhibitory activity against $S$. aureus at least with one extract (Table 2). There was not much difference in activity across the different extracts of the same plant when tested against $S$. aureus. Plants such as A. salviifolium, A. scholaris, Antidesma bunius, B. racemosa, 


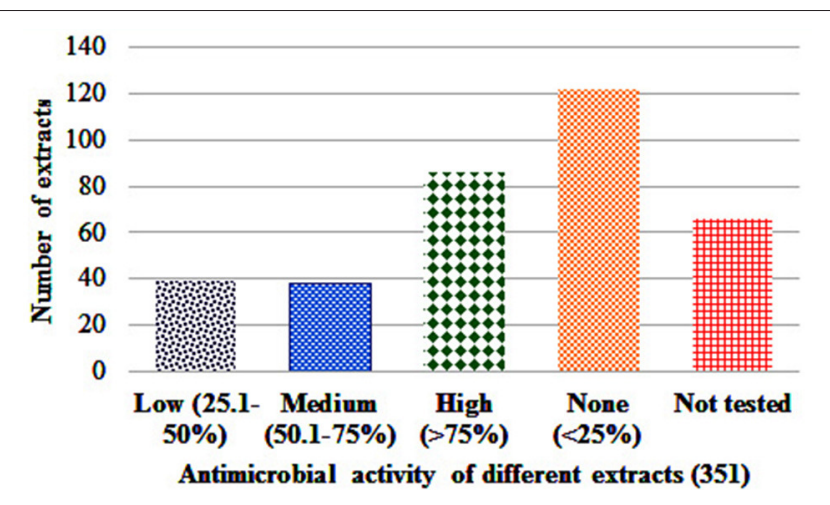

FIGURE 4 | Antimicrobial activity score of different extracts.

C. arborea, C. patulus, C. oppositifolia, H. gaitii, H. pubescens, $M$. malabathricum, $R$. ellipticus, and $P$. serratum have inhibitory activity against $S$. aureus with all three extracts (acetone, water, and ethanol). Plants such as A. salviifolium, A. octandra, B. acutangula, B. racemosa, C. arborea, C. graveolens, C. pallida, C. roxburghii, D. pentagyna, $H$. pubescens, L. coromandelica, M. peltata, M. malabathricum, M. rubicaulis, R. ellipticus, $S$. multiflora, and $W$. arborea showed broad-spectrum activity by inhibiting both Gram-positive and Gram-negative bacteria.

Plants such as $A$. scholaris, B. monosperma, C. arborea, $C$. graveolens, C. pallida, C. roxburghii, H. pubescens, D. malbarica, G. arborea, M. peltata, P. serratum, P. acerifolium, R. ellipticus, and $S$. multiflora showed activity against C. albicans (Table 2). Like for E. coli, C. albicans also responded differently to extracts of the same plant in different solvents. Ethanol is the best overall extractant (14 plants) followed by acetone (8) and water (3). C. arborea, C. graveolens, C. pallida, C. roxburghii, $H$. pubescens, $M$. peltata, R. ellipticus, and S. multiflora were active against all three test strains: E. coli, S. aureus, and C. albicans.

\section{Anthelmintic Activity}

Table 4 shows the \% inhibition (those surpassing 50 are underlined) on $C$. elegans after treatment with $1 \mu$ l of extract. Out of the 35 test plants, 22 plant viz. A. salviifolium, A. bunius, A. octandra, B. acutangula, C. graveolens, C. pallida, C. patulus, G. arborea, H. pubescens, H. gaitii, L. coromandelica, M. peltata, M. malabathricum, M. extensa, N. arbor-tristis, P. serratum, $P$. acerifolium, $R$. ellipticus, S. multiflora, S. cochinchinensis, $V$. maderaspatana, and $W$. arborea showed promising activity.

\section{Antiviral Activity}

The effect of different plant extracts on the inhibition of enterovirus (type $71, \mathrm{BrCr}$ ) is presented in Table 5. Of the 35 plants tested, 5 acetone and 5 ethanol extracts, as well as 10 aqueous extracts showed potent inhibitory activity (higher than 50\%). These active extracts were subsequently tested for cytotoxicity, and the effective concentration protecting 50 or $90 \%$ of the cells $\left(\mathrm{EC}_{50}\right.$ and $\left.\mathrm{EC}_{50}\right)$ as well as cytotoxic concentration $\left(\mathrm{CC}_{50}\right)$ are presented in Table 5. Additionally, the Selectivity Index (SI), Selectivity Surface (SS), and Therapeutic Index (TI) were calculated from the dose-response curves (Supplementary Figure 1). Among these plants, A. bunius, C. graveolens, $C$. patulus, C. oppositifolia, H. gaitii, M. extensa, P. serratum, $R$. ellipticus, and $V$. maderaspatana showed the best activity and could be suitable for finding antiviral compounds.

\section{DISCUSSION}

Since ancient time, plants are well-known as a source of medicine for the treatment of diverse diseases, and they continue to serve as the basis for many pharmaceuticals used today. They are a rich bio-resource for drugs of traditional medicinal systems, modern medicines, nutraceuticals, food supplements, folk medicines, pharmaceuticals, intermediates, and chemicals for synthetic drugs (Hammer et al., 1999). Medicinal uses are well-described in the Indian Ayurveda (Patwardhan, 2005), in Traditional Chinese Medicine (Wan et al., 2016), and in various European historical documents (Ginsburg and Deharo, 2011). However, indigenous knowledge in a particular region is an important component of traditional medicine, which is widely practiced by the tribal communities throughout India. The traditional medicines not only provide valuable clues for finding new drugs, but also help to shift the drug discovery paradigm from "finding new-entity drugs" to "combining existing agents," and might even guide the combinations between such agents (Wagner and UlrichMerzenich, 2009).

From the different test performed in the present study, we conclude that $C$. arborea, C. graveolens, C. pallida, C. roxburghii, $H$. pubescens, M. peltata, R. ellipticus, and S. multiflora could be potential sources for broad-spectrum antibiotics as they inhibit all three test strains: E. coli (a model Gram-), S. aureus (a model Gram +), and C. albicans (the most common human pathogenic fungus). Moreover, plants such as A. salviifolium, A. bunius, $B$. racemosa, C. patulus, C. oppositifolia, $H$. gaitii, and $P$. serratum can be a useful source for narrow-spectrum antibiotics against $S$. aureus, while plants such A. scholaris, B. monosperma, D. malbarica, G. arborea, and $P$. acerifolium could yield antifungal agents. Thus, the indigenous knowledge by the tribals of the SBR appears to be a promising source for antimicrobial agents.

In this study, 19 plants parts were used traditionally to treat various skin infections, 17 plant parts for diarrhea and six plant parts for dysentery. In the present study, it was experimentally demonstrated that most plants used by tribals of Similipal (Mayurbhanj district), are potential sources of natural antibiotics. According to Williamson et al. (1996), the extraction procedure can be guided by how the plant is used in folk medicine. The tribals of SBR mostly use aqueous extracts (infusion/decoction). We observed that aqueous extracts frequently produce inhibitory effects against both bacterial strains, while they are rarely effective against C. albicans. We also found that some plants show activity in both polar and non-polar solvents, and sometime in all three extracts. This suggests that different active compounds are present, which may show additive or synergistic effects when the complete plant is used for treatment.

The plant extracts were most often active on $S$. aureus, followed by E. coli and finally C. albicans. Plant extracts typically 
TABLE 3 | Determination of $\mathrm{MIC}_{50}$ of selected extracts (concentration in $\mu \mathrm{g} / \mathrm{mL}$ ).

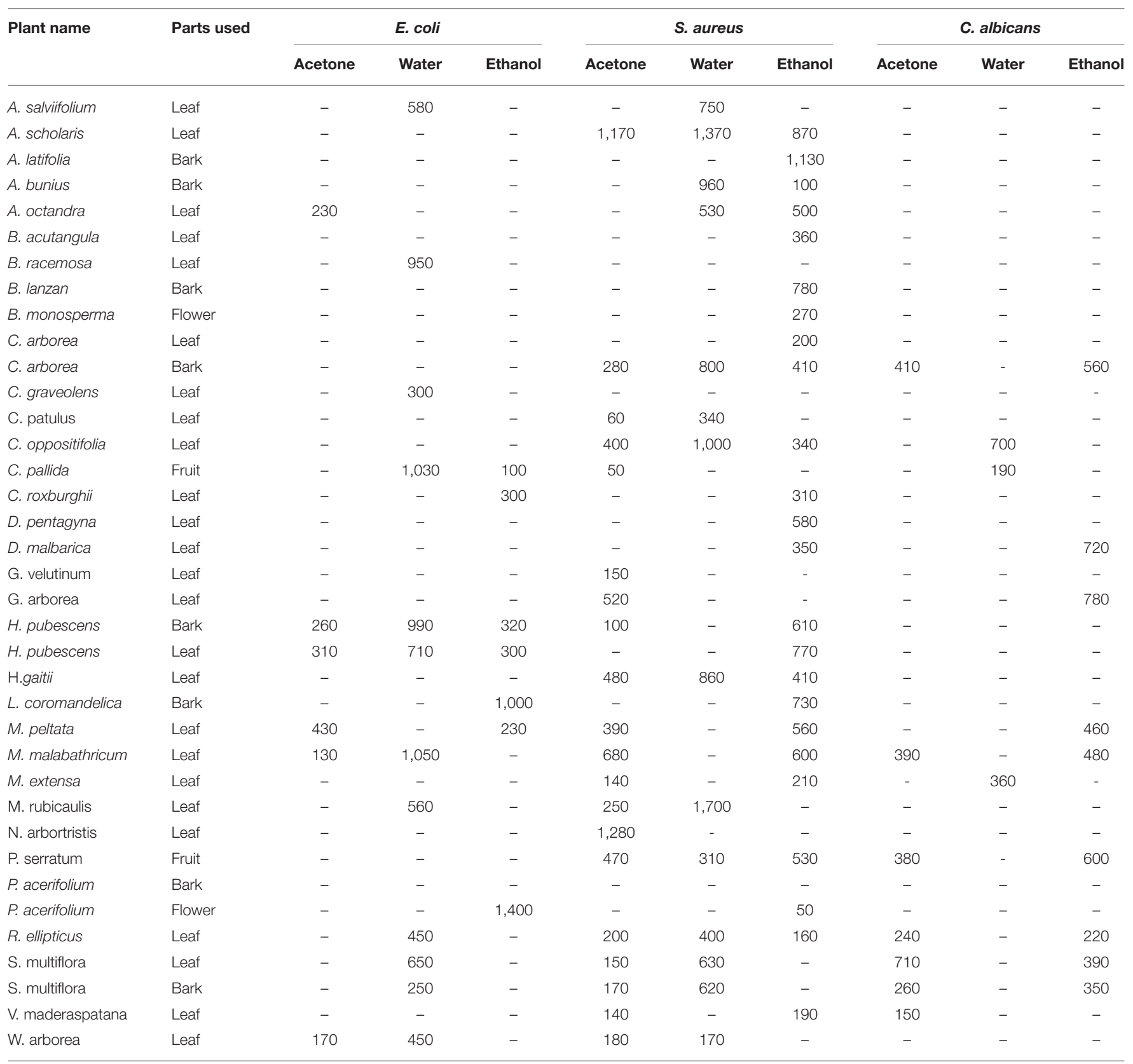

(-) Data absent; MIC $C_{50}$ value were rounded to the nearest integer.

show stronger inhibition on Gram-positive than Gram-negative bacteria (Desta, 1993). The latter are in general more resistant to the action of antimicrobials compared to the former because of a more complex cell wall (Silhavy et al., 2010).

Like bacterial and fungal infections, parasitic infections pose also major global health problems in humans and animals. Nematode parasites cause serious problems in the livestock industry due to drug resistance in several helminth species (Prichard, 1994; Perry and Randolph, 1999). The traditional practitioners have extensive knowledge about the treatment of parasitic infections. Therefore, we screened for extracts active on C. elegans, which has recently received increased attestation as a model organism for drug discovery (Desalermos et al., 2011). In the present study, of the 83 plant extracts tested, 30 had pronounced anthelmintic activity ( $>50 \%$ activity inhibition). More than half of the extracts show some activity (defined arbitrarily as activity inhibition by more than $25 \%$ ). This suggests the accuracy of the use of plants by the tribes of the SBR. The plant extracts that inhibited the activity of $C$. elegans can be promising starting points in the search for anthelmintic drugs.

In addition to antibacterial, antifungal, and anthelmintic properties, the crude extracts were also evaluated for antiviral 
TABLE 4 | Anthelmintic activity of selected extracts of plants collected from SBR, India.

\begin{tabular}{|c|c|c|c|c|}
\hline \multirow[t]{2}{*}{ Taxonomic name } & \multirow[t]{2}{*}{$\begin{array}{l}\text { Parts } \\
\text { used }\end{array}$} & \multicolumn{3}{|c|}{$\begin{array}{c}\% \text {, relative movement compared to } \\
\text { the solvent }\end{array}$} \\
\hline & & Acetone & Water & Ethanol \\
\hline A. salviifolium & Leaf & $79 \pm 9$ & $119 \pm 5$ & $77 \pm 10$ \\
\hline A. scholaris & Leaf & - & - & $73 \pm 24$ \\
\hline A. latifolia & Bark & - & - & $\underline{25} \pm 6$ \\
\hline A. bunius & Bark & $\underline{24} \pm 3$ & $81 \pm 10$ & $66 \pm 6$ \\
\hline A. octandra & Leaf & $\underline{15} \pm 5$ & $62 \pm 6$ & $\underline{16} \pm 17$ \\
\hline B. acutangula & Leaf & - & - & $\underline{47} \pm 4$ \\
\hline B. racemosa & Leaf & $100 \pm 16$ & $73 \pm 25$ & $89 \pm 10$ \\
\hline B. lanzan & Bark & - & - & $99 \pm 2$ \\
\hline B. monosperma & Flower & - & - & $96 \pm 8$ \\
\hline C. arborea & Leaf & - & - & $72 \pm 8$ \\
\hline C. arborea & Bark & $72 \pm 10$ & $101 \pm 16$ & $77 \pm 16$ \\
\hline C. graveolens & Leaf & $\underline{28} \pm 3$ & $79 \pm 5$ & $83 \pm 11$ \\
\hline C. patulus & Leaf & $\underline{45} \pm 1$ & $86 \pm 6$ & $69 \pm 16$ \\
\hline C. oppositifolia & Leaf & $55 \pm 7$ & $99 \pm 8$ & $83 \pm 2$ \\
\hline C. pallida & Fruit & $\underline{37} \pm 6$ & $132 \pm 11$ & $101 \pm 1$ \\
\hline C. roxburghii & Leaf & - & - & $86 \pm 1$ \\
\hline D. pentagyna & Leaf & - & - & $110 \pm 3$ \\
\hline D. malbarica & Leaf & - & - & $83 \pm 8$ \\
\hline E. rheedii & Seed & $61 \pm 6$ & $112 \pm 33$ & $88 \pm 4$ \\
\hline G. velutinum & Leaf & $72 \pm 10$ & $86 \pm 4$ & $116 \pm 8$ \\
\hline G. arborea & Leaf & $\underline{39} \pm 5$ & $126 \pm 20$ & $\underline{34} \pm 9$ \\
\hline H. pubescens & Bark & - & - & $\underline{35} \pm 4$ \\
\hline H. pubescens & Leaf & - & - & $\underline{37} \pm 10$ \\
\hline H. gaitii & Leaf & $\underline{30} \pm 9$ & $80 \pm 5$ & $56 \pm 2$ \\
\hline L. coromandelica & Bark & - & - & $\underline{16} \pm 8$ \\
\hline M. peltata & Leaf & $\underline{40} \pm 5$ & $92 \pm 2$ & $53 \pm 4$ \\
\hline M. malabathricum & Leaf & $66 \pm 15$ & $66 \pm 15$ & $\underline{31} \pm 12$ \\
\hline M. extensa & Leaf & $\underline{43} \pm 4$ & $88 \pm 3$ & $\underline{11} \pm 13$ \\
\hline M. rubicaulis & Leaf & $66 \pm 17$ & $100 \pm 2$ & $72 \pm 8$ \\
\hline N. arbortristis & Leaf & $\underline{35} \pm 4$ & $79 \pm 11$ & $\underline{36} \pm 8$ \\
\hline P. serratum & Fruit & $\underline{37} \pm 11$ & $80 \pm 19$ & $\underline{28} \pm 1$ \\
\hline P. acerifolium & Bark & - & - & $92 \pm 2$ \\
\hline P. acerifolium & Flower & - & - & $55 \pm 2$ \\
\hline R. ellipticus & Leaf & $69 \pm 13$ & $104 \pm 3$ & $\underline{49} \pm 1$ \\
\hline S. multiflora & Leaf & $96 \pm 8$ & $110 \pm 6$ & $62 \pm 4$ \\
\hline S. multiflora & Bark & $82 \pm 11$ & $82 \pm 37$ & $\underline{36} \pm 3$ \\
\hline S. cochinchinensis & Leaf & $108 \pm 6$ & $35 \pm 16$ & $79 \pm 16$ \\
\hline V. maderaspatana & Leaf & $\underline{41} \pm 9$ & $72 \pm 25$ & $\underline{28} \pm 11$ \\
\hline W. arborea & Leaf & $\underline{49} \pm 1$ & $108 \pm 16$ & $\underline{36} \pm 18$ \\
\hline Levamisole & & $\underline{48} \pm 3$ & $53 \pm 4$ & $\underline{41} \pm 10$ \\
\hline
\end{tabular}

(-) Data absent, all values are listed as mean $\pm S D$; data were rounded to the nearest integer. Underlined values represent above 50 inhibition.

activity using enterovirus type $71, \mathrm{BrCr}$ strain. The genus Enterovirus is responsible for a wide variety of diseases including meningitis, myocarditis, encephalitis and respiratory diseases (Bruu, 2002). There is currently no effective drug for the treatment of EV71 infections. The $\mathrm{EC}_{50}$ and $\mathrm{CC}_{50}$ were determined for active extracts from the dose-response curves. Considering the Selectivity Index, Selectivity Surface and Therapeutic Index, the crude extracts of A. bunius (bark), C. graveolens (leaf), C. patulus (leaf), C. oppositifolia (leaf), H. gaitii (leaf), M. extensa (leaf), P. serratum (fruit), R. ellipticus (leaf), and $V$. maderaspatana (leaf) demonstrate potential anti-enteroviral activity.

In the present study for selected extracts, cytotoxic activity was determined by calculating the $\%$ of surviving cells across a range of concentrations (1-100 $\mu \mathrm{g} / \mathrm{mL})$. Several plants show significant antiviral effects with no significant cytotoxicity, thus proving safe at least for mammalian cells.

Based on our review of the literature, the antimicrobial activity of A. octandra, C. graveolens, C. patulus, D. pentagyna, G. velutinum, $H$. gaitii, L. coromandelica, M. extensa, M. rubicaulis, P. serratum, R. ellipticus, S. multiflora, S. cochinchinensis and $W$. arborea has not been documented so far, while plants such as A. salviifolium (Jain et al., 2010), A. scholaris (Khan et al., 2003; Hussain et al., 2010), A. latifolia (Govindarajan et al., 2006; Patil and Gaikwad, 2010), A. bunius (Lizardo et al., 2015), B. acutangula (Sahoo et al., 2008), B. racemosa (Rashed and Butnariu, 2014), B. lanzan (Pattnaik et al., 2013), B. monosperma (Tiwari et al., 2012; Sahu and Padhy, 2013), C. arborea (Kumar et al., 2006) C. oppositifolia (Mahapatra et al., 2013), C. pallida (Ukil et al., 2016), C. roxburghii (Thatoi et al., 2008; Panda et al., 2010a,b), D. malbarica (Panda et al., 2012), G. arborea (Khan et al., 2003; El-Mahmood et al., 2010), H. pubescens (Chakraborty and Brantner, 1999; Siddiqui et al., 2012), M. malabathricum (Alwash et al., 2014), M. peltata (Bijesh and Sebastian, 2013), N. arbor-tristis (Aggarwal and Goyal, 2013), P. acerifolium (Panda and Dutta, 2012), and V. maderaspatana (Kawde et al., 2014) were reported before to show antimicrobial effects. Likewise, $A$. salviifolium (Pandey, 2012), B. acutangula (Padmavathi et al., 2011), C. pallida (Panda et al., 2014), G. arborea (Panda et al., 2015), H. pubescens (Satpute et al., 2014), M. malabathricum (Suteky and Dwatmadji, 2011), and N. arbor-tristis (Shruti et al., 2009) were reported earlier for anthelmintic properties, while plants such as A. bunius, A. octandra, C. graveolens, C. patulus, H. gaitii, L. coromandelica, M. peltata, M. extensa, P. serratum, $P$. acerifolium, R. ellipticus, S. multiflora, S. cochinchinensis, $V$. maderaspatana, and $W$. arborea are reported for the first time here to inhibit $C$. elegans. However, three plants, namely $A$. scholaris (Singh and Sharma, 2013), B. racemosa (Kumar et al., 2011), and B. monosperma (Prashanth et al., 2001; Sant et al., 2014), were reported earlier for anthelmintic activity, but did not show significant inhibition of $C$. elegans in the present study. This may be due to differences in test organism, test conditions or concentrations used. Concerning antiviral studies, A. scholaris (Antony et al., 2014) and B. monosperma (Yadava and Tiwari, 2005), were previously reported, while plants such as A. bunius, C. graveolens, C. patulus, C. oppositifolia, H. gaitii, $M$. extensa, $P$. serratum, $R$. ellipticus, and $V$. maderaspatana showed the highest activity and could be suitable for finding antiviral compounds.

Zhu et al. (2011) published a review on nature-derived drugs, where they analyzed "the ranking of drug-productive plant families based on the ratio of the approved drugs to reported bioactive natural products (including leads of the approved and clinical trials drugs)" and concluded that the 
TABLE 5 | Antiviral and cytotoxic activity of selected extracts of plants collected from SBR, India.

\begin{tabular}{|c|c|c|c|c|c|c|c|c|c|}
\hline Plant name & Parts used & Extract tested & $\mathrm{EC}_{50}(\mu \mathrm{g} / \mathrm{ml})$ & $E C_{90}(\mu \mathrm{g} / \mathrm{ml})$ & Max. \% inhibition & $\mathrm{CC}_{50}(\mu \mathrm{g} / \mathrm{ml})$ & SI & ss & TI \\
\hline A. latifolia & Bark & Acetone & 66 & $>100$ & 53 & 77 & 1 & 0 & 0 \\
\hline A. bunius & Bark & Ethanol & $71 \pm 22$ & $87 \pm 3$ & $63 \pm 6$ & $98 \pm 3$ & $2 \pm 1$ & $1 \pm 2$ & $1 \pm 1$ \\
\hline B. racemosa & Leaf & Ethanol & $43 \pm 6$ & $>100$ & $79 \pm 1$ & $>75$ & $>2$ & $>3$ & $>1$ \\
\hline C. graveolens & Leaf & Aqueous & $3 \pm 1$ & $4 \pm 1$ & $100 \pm 0$ & $>100$ & $>28$ & $>18$ & $>26$ \\
\hline C. patulus & Leaf & Aqueous & $35 \pm 15$ & $>100$ & $85 \pm 19$ & $>75$ & $>2$ & $>3$ & $>2$ \\
\hline C. oppositifolia & Leaf & Aqueous & $82 \pm 17$ & $>100$ & $63 \pm 1$ & $>100$ & $>1$ & $>1$ & $>1$ \\
\hline G. velutinum & Leaf & Acetone & 9 & 19 & 70 & 26 & 3 & 4 & 2 \\
\hline H. gaitii & Leaf & Aqueous & $70 \pm 26$ & $>100$ & $69 \pm 6$ & $>100$ & $>2$ & $>3$ & $>1$ \\
\hline M. peltata & Leaf & Aqueous & $20 \pm 1$ & $81 \pm 4$ & $79 \pm 7$ & $100 \pm 0$ & $5 \pm 0$ & $11 \pm 3$ & $8 \pm 2$ \\
\hline M. malabathricum & Leaf & Acetone & $14 \pm 2$ & $>75$ & $62 \pm 4$ & $20 \pm 0$ & $2 \pm 1$ & $1 \pm 0.1$ & $0.1 \pm 0.1$ \\
\hline M. malabathricum & Leaf & Ethanol & $46 \pm 5$ & $>100$ & $76 \pm 1$ & $>75$ & $>2$ & $>4$ & $>1$ \\
\hline M. extensa & Leaf & Aqueous & $42 \pm 17$ & $>100$ & $90 \pm 14$ & $>100$ & $>2$ & $>4$ & $>2$ \\
\hline M. rubicaulis & Leaf & Aqueous & $54 \pm 1$ & $>100$ & $81 \pm 1$ & $>100$ & $>2$ & $>4$ & $>1$ \\
\hline P. serratum & Fruit & Ethanol & $15 \pm 7$ & $57 \pm 44$ & $99 \pm 2$ & $>100$ & $>5$ & $>12$ & $>10$ \\
\hline R. ellipticus & Leaf & Aqueous & $5 \pm 5$ & $8 \pm 6$ & $88 \pm 18$ & $59 \pm 3$ & $18 \pm 16$ & $28 \pm 17$ & $36 \pm 33$ \\
\hline R. ellipticus & Leaf & Ethanol & $13 \pm 6$ & $15 \pm 0$ & $74 \pm 1$ & $29 \pm 4$ & $3 \pm 1$ & $3 \pm 2$ & $2 \pm 1$ \\
\hline V. maderaspatana & Leaf & Aqueous & $74 \pm 44$ & $>100$ & $70 \pm 28$ & $>100$ & $>1$ & $>1$ & $>1$ \\
\hline W. arborea & Leaf & Acetone & 12 & - & 59 & 18 & 1 & 1 & 0 \\
\hline W. arborea & Leaf & Aqueous & $12 \pm 5$ & $>75$ & $89 \pm 1$ & $>100$ & $>10$ & $>11$ & $>11$ \\
\hline Rupintrivir & & & $0.02 \pm 0.001 \mu \mathrm{M}$ & $0.03 \pm 0.001 \mu \mathrm{M}$ & $100 \pm 0$ & $>10 \mu \mathrm{M}$ & - & - & - \\
\hline
\end{tabular}

$E C_{50}=50 \%$ Effective Concentration (concentration at which $50 \%$ inhibition of virus replication is observed).

$E C_{90}=90 \%$ Effective Concentration (concentration at which $90 \%$ inhibition of virus replication is observed).

$C_{50}=50 \%$ Cytostatic/Cytotoxic Concentration (concentration at which 50\% adverse effect is observed on RD cells in parallel with antiviral assay).

$\mathrm{SI}=$ Selectivity Index $\left(\mathrm{CC}_{50} / \mathrm{EC}_{50}\right)$.

$S S=$ Selectivity Surface (integrated surface delineated by the $E_{50}$ curve, the $C_{50}$ curve and the $50 \%$ horizontal).

$T I=$ Therapeutic Index (SS*10logSI).

(-) Data absent; all values are listed as mean $\pm S D$; data were rounded to the nearest integer.

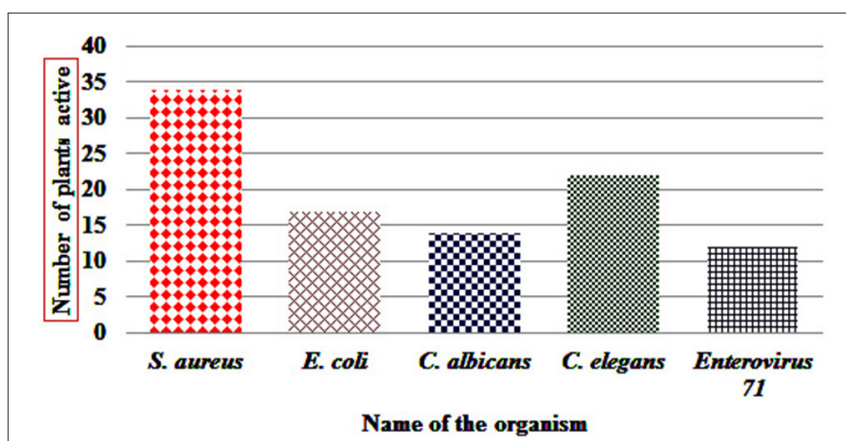

FIGURE 5 | Number of SBR plants with at least one extract showing activity (>50\%) against tested organism.

top-ranked families that produce high numbers of approved drugs among the plant-derived medicines were Fabaceae, Ephedraceae, Papaveraceae, Asteraceae, Solanaceae, Rubiaceae, and Apocynaceae. Girach and his "co-workers" findings (1999) show that eight families appear in the top 15 on the list of highuse families of Similipal viz. Euphorbiaceae, Caesalpiniaceae, Asteraceae, Lamiaceae, Malvaceae, Mimosaceae, Rubiaceae, and Solanaceae. Most of these families are also confirmed active by bioassay in the present study. Our screening results suggest that the top families with bioactivity for infections are Euphorbiaceae, Leguminosae, Apocyanaceae, Phyllanthaceae, Fabaceae, Anacardiaceae, Lamiaceae, and Lecythidaceae.

Although there are a lot of papers published on medicinal plants from India, they mostly neglect the rich traditional knowledge of the tribal peoples. To the best of our knowledge, this paper is the first systematic bioactivity study of medicinal plants from the SBR based on traditional knowledge of indigenous tribes. However, many previous studies have not determined systematically whether such traditionally used species are more likely to yield useful bioactive compounds. It therefore remains controversial whether traditionally used plants form a good starting point for drug discovery (Fabricant and Farnsworth, 2001; Soejarto et al., 2005) and prospection guided by ethnobotany has fluctuated (Cox and Balick, 1994; Firn, 2003; Newman and Cragg, 2016). One view is that "traditionally used medicinal plants are not necessarily efficacious and there are no robust methods for distinguishing those which are most likely to be bioactive when selecting species for further testing" quoted by Saslis-Lagoudakis et al. (2012). Saslis-Lagoudakis et al. (2012), published a review entitled "phylogenies reveal the predictive power of traditional medicine in bioprospecting," and conclude that "phylogenetic cross-cultural comparisons 
can focus screening efforts on a subset of traditionally used plants that are richer in bioactive compounds, and could revitalize the use of traditional knowledge in bioprospecting". Their study provides unique large-scale evidence that plant bioactivity underlies traditional medicine. Our results agree with this view.

\section{CONCLUSION}

The present study shows the importance of indigenous knowledge of the tribes of the SBR for selecting plants with potential for treating infectious diseases. This knowledge obtained from the tribals and combined with taxonomy, toxicity, and different biological activities demonstrates the value of healing practices and the use of plants by the tribes of the SBR and suggests that bioprospecting of medicinal plants with the help of traditional knowledge of indigenous peoples is useful for the discovery of new drug candidates. However, further scientific studies on isolating the active compounds are essential to discover novel candidate drugs.

\section{AUTHOR CONTRIBUTIONS}

Conceived and designed the experiments: SP, ML, and PL. Performed the experiments: SP, LP, ML, and PL. Analyzed the data: SP, PL, and WL. Contributed reagents/materials/analysis tools: SP, PL, JN, and WL. Contributed to the writing of the manuscript: SP and WL.

\section{FUNDING}

The author SP was financial supported by receipt of a postdoc fellowship from EMINTE (Erasmus Mundus, EU; http://eminte.eu/).

\section{REFERENCES}

Aggarwal, S. G., and Goyal, S. (2013). Nyctanthes arbor-tristis against pathogenic bacteria. J. Pharmacol. Phytochem. 2, 124-127.

Alwash, M. S. A., Ibrahim, N., Yaacob, W. A., and Din, L. B. (2014). Antibacterial, antioxidant and cytotoxicity properties of traditionally used Melastoma malabathricum Linn. leaves. Adv. J. Food Sci. Technol. 6, 6-12. doi: 10.19026/ajfst.6.3022

Antony, M., Mishra, C. S., and Thankamani, V. (2014). Evaluation of active fraction from plant extracts of Alstonia scholaris for its in-vitro and in-vivo antiviral activity. Int. J. Pharm Pharma Sci. 6, 775-781.

Bijesh, K., and Sebastian, D. (2013). Isolation and characterization of antibacterial compounds from Macaranga peltata against clinical isolates of Staphylococcus aureus. Int. J. Biol. Pharma Res. 4, 1196-1203.

Brenner, S. (1974). The genetics of Caenorhabditis elegans. Genetics 77, 71-94.

Bruu, A.-L. (2002). "Enteroviruses: polioviruses, coxsackieviruses, echoviruses and newer enteroviruses," in A Practical Guide to Clinical Virology, 2nd Edn., eds L. R. Haaheim, J. R. Pattison, and R. J. Whitley (Chichester, UK: John Wiley \& Sons, Ltd.). doi: 10.1002/0470857285.ch6

Chakraborty, A., and Brantner, A. H. (1999). Antibacterial steroid alkaloids from the stem bark of Holarrhena antidysenterica. J. Ethnopharmacol. 68, 339-344. doi: 10.1016/S0378-8741(99)00119-1

Cox, P. A., and Balick, M. J. (1994). The ethnobotanical approach to drug discovery. Sci. Am. 270, 82-87. doi: 10.1038/scientificamerican0694-82

\section{ACKNOWLEDGMENTS}

The authors wish to thank the authorities of North Orissa University for providing necessary facilities for the collection, identification, and extraction of plant materials. We are also thankful to the PCCF and Field Director, STR cum RCCF, Baripada, Odisha to provide permission for field visits at SBR (2013-14) Special thanks go to Dr. Anil K. Biswal, Dr. A. K. Bastia, Mr. Kishore K. Mondal (North Orissa University), and Dr. Sanat Das (Ayurveda doctor, Badasahi, Mayurbahnj) for identification of the plant samples. Thanks also to Dr. Gunanidhi Sahoo, Niranjan Patra, Yugal K. Mohanta, Sukumar Bhakta, Himanshu S. Palei, and Santanu K. Jena (North Orissa University), for the collection of plant samples and expert technical help during experiments. The authors are thankful to Yipeng $\mathrm{Ma}$ (KU Leuven), who helped in writing the antiviral part and provided critical suggestions for this manuscript. The author SP is also grateful for financial support on receipt of a postdoc fellowship from EMINTE (Erasmus Mundus, EU; http://eminte.eu/). PL is supported by the Flemish IOF (Industrial Research Fund), ML is supported by a CSC fellowship of the Chinese government, and WL largely supported himself. Finally, we wish to thank countless tribal informants, especially Rathu Mohanta and Subash Kumar Mohanta, as they traveled with SP and helped with the collection of plants, provided traditional uses of plants and help in communicating in vernacular languages. We hope that the information produced from these studies will be of use to them and their fellow tribals in the future.

\section{SUPPLEMENTARY MATERIAL}

The Supplementary Material for this article can be found online at: https://www.frontiersin.org/articles/10.3389/fphar. 2017.00658/full\#supplementary-material

Desalermos, A., Muhammed, M., Glavis-Bloom, J., and Mylonakis, E. (2011). Using Caenorhabditis elegans for antimicrobial drug discovery. Expert Opin. Drug Discov. 6, 645-652. doi: 10.1517/17460441.2011. 573781

Desta, B. (1993). Ethiopian traditional herbal drugs Part II. Antimicrobial activity of 63 medicinal plants. J. Ethnopharmacol. 39, 129-139. doi: 10.1016/0378-8741(93)90028-4

El-Mahmood, A. M., Doughari, J. H., and Kiman, H. S. (2010). In vitro antimicrobial activity of crude leaf and stem bark extracts of Gmelina arborea (Roxb) against some pathogenic species of Enterobacteriaceae. Afr. J. Pharma Pharmacol. 4, 355-361.

Fabricant, D. S., and Farnsworth, N. R. (2001). The value of plants used in traditional medicine for drug discovery. Environ. Health Perspect. 109, 69-75. doi: 10.1289/ehp.01109s169

Firn, R. D. (2003). Bioprospecting - why is it so unrewarding? Biodivers. Conserv. 12, 207-216. doi: 10.1023/A:1021928209813

Fonzi, W. A., and Irwin, M. Y. (1993). Isogenic strain construction and gene mapping in Candida albicans. Genetics 134, 717-728.

Fyhrquist, P. (2007). Traditional Medicinal Uses and Biological Activities of Some Plant Extracts of African Combretum Loefl., Terminalia L. and Pteleopsis Engl. Species (Combretaceae). Academic dissertation, University of Helsinki.

Ginsburg, H., and Deharo, E. (2011). A call for using natural compounds in the development of new antimalarial treatments-an introduction. Malar. J. 10:S1. doi: $10.1186 / 1475-2875-10-S 1-S 1$ 
Girach, R. D., Shaik, A. A., Singh, S. S., and Ahmad, M. (1999). The medicinal flora of Similipahar forests, Orissa State, India. J. Ethnopharmacol. 65, 165-172. doi: 10.1016/S0378-8741(98)00146-9

Govindarajan, R., Vijayakumar, M., Singh, M., Rao, C. V., Shirwaikar, A., Rawat, A. K. S., et al. (2006). Antiulcer and antimicrobial activity of Anogeissus latifolia. J. Ethnophrmacol. 106, 57-61. doi: 10.1016/j.jep.2005.12.002

Gurib-Fakim, A. (2005). Medicinal plants: traditions of yesterday and drugs of tomorrow. Mol. Aspects Med. 27, 1-93. doi: 10.1016/j.mam.2005. 07.008

Hammer, K. A., Carson, C. F., and Riley, T. V. (1999). Antimicrobial activity of essential oils and other plant extracts. J. Appl. Microbiol. 86, 985-990. doi: 10.1046/j.1365-2672.1999.00780.x

Hussain, A., Zaman, M. K., and Ramteke, A. M. (2010). Antibacterial activity of trunk bark of Alstonia scholaris. Asian J. Pharmaceut. Clin. Res. 3, 46-47.

Jain, V. C., Patel, N. M., Shah, D. P., Patel, P. K., and Joshi, B. H. (2010). Antioxidant and antimicrobial activities of Alangium salvifolium (Lf) Wang root. Global J. Pharmacol. 4, 13-18.

Kawde, A. B., Batra, R. J., Weginwar, R. G., Akkewar, D. M., Gond, G. S., and Aparna, Y. (2014). Preliminary phytochemical screening and bioevaluation studies of stem bark of Ventilago madersapatana Garten. Int. J. Res. Pharma Chem. 4, 74-82.

Khan, M. R., Omoloso, A. D., and Kihara, M. (2003). Antibacterial activity of Alstonia scholaris and Leea tetramera. Fitoterapia 74, 736-740. doi: 10.1016/S0367-326X(03)00192-8

Kumar, R. S., Sivakumar, T., Sundaram, R. S., Sivakumar, P., Nethaji, R., Gupta, M., et al. (2006). Antimicrobial and antioxidant activities of Careya arborea Roxb. stem bark. Iran J. Pharm. Ther. 5, 35-41.

Kumar, T., Alexander, A., Dewangan, A. D., Khan, J., and Sharma, M. (2011). Investigation of in-vitro anthelmintic activity of Bauhinia racemosa Linn. J. Appl. Pharm. Sci. 1, 73-75.

Lenaerts, I., Walker, G. A., Van Hoorebeke, L., Gems, D., and Vanfleteren, J. R. (2008). Dietary restriction of Caenorhabditis elegans by axenic culture reflects nutritional requirement for constituents provided by metabolically active microbes. J. Gerontol. A63, 242-252. doi: 10.1093/gerona/63.3.242

Lizardo, R. C. M., Mabesa, L. B., Dizon, E. I., and Aquino, N. A. (2015). Functional and antimicrobial properties of bignay [Antidesma bunius (L.) Spreng.] extract and its potential as natural preservative in a baked product. Int. Food Res. J. 22, 88-95.

Mahapatra, S. K., Mookerjee, M., Roy, D. S., Karak, P., Das, S., and Dastidar, S. G. (2013). Evaluation of antimicrobial potentiality of a flavonoid, isolated from the leaf of the plant Colebrookea Oppositifolia. Int. J. Biol. Pharm. Res. 4, 225-230.

Martínez-Gualda, B., Sun, L., Rivero-Buceta, E., Flores, A., Quesada, E., Balzarini, J., et al. (2017). Structure-activity relationship studies on a Trp dendrimer with dual activities against HIV and enterovirus A71. Modifications on the amino acid. Antiviral Res. 139, 32-40. doi: 10.1016/j.antiviral.2016.12.010

Newman, D. J., and Cragg, G. M. (2016). Natural products as sources of new drugs from 1981 to 2014. J. Nat. Prod. 79, 629-661. doi: 10.1021/acs.jnatprod.5b01055

Padmavathi, D., Bharathi, R. V., and Sarala, A. (2011). In vitro anthelmintic activity of ethanolic extracts of Barringtonia acutangula (L.) Geartn. Int. J. Pharm Technol. Res. 3, 784-786.

Panda, S. K. (2014). Ethno-medicinal uses and screening of plants for antibacterial activity from similipal biosphere reserve. Odisha, India. J. Ethnopharmacol. 151, 158-175. doi: 10.1016/j.jep.2013.10.004

Panda, S. K., and Dutta, S. K. (2012). Antibacterial activity from bark extracts of Pterospermum acerifolium (L.) Willd. Int. J. Pharma Sci. Res. 2, 584-595.

Panda, S. K., Bastia, A. K., and Dutta, S. K. (2010a). Anticandidal activity of Croton roxburghii Balak. Int. J. Curr. Pharma Res. 2, 55-59.

Panda, S. K., Das, D., and Tripthathy, N. K. (2014). Phytochemical investigation and anthelmintic activity of various leaf extracts of Crotalaria pallida Aiton. World J. Pharma Pharmaceut. Sci. 4, 336-342.

Panda, S. K., Das, D., and Tripthathy, N. K. (2015). Phytochemical investigation and anthelmintic activity of various root extracts of Gmelina arborea. Asian J. Plant Sci. Res. 5, 54-58.

Panda, S. K., Dutta, S. K., and Bastia, A. K. (2010b). Antibacterial activity of Croton roxburghii Balak. against the enteric pathogens. J. Adv. Pharma Technol. Res. 1, 388-391. doi: 10.4103/0110-5558.76442

Panda, S. K., Mohanta, Y. K., Padhi, L., Park, Y. H., Mohanta, T. K., and Bae, H. (2016). Large scale screening of ethnomedicinal plants for identification of potential antibacterial compounds. Molecules 21, 1-20. doi: 10.3390/molecules21030293

Panda, S. K., Patra, N., Sahoo, G., Bastia, A. K., and Dutta, S. K. (2012). Antidiarrheal activities of medicinal plants of Similipal Biosphere Reserve, Odisha, India. Int. J. Med. Arom. Plants 2, 123-134.

Pandey, R. S. (2012). Anthelmintic activity of Alangium salviifolium bark. J. Nat. Prod. Plant Resour. 2, 717-720.

Patil, U. H., and Gaikwad, D. K. (2010). Phytochemical profile and Antibacterial activity of stem bark of Anogeissus latifolia. Phrmacogn. J. 17, 70-73. doi: 10.1016/S0975-3575(10)80014-8

Pattnaik, A., Sarkar, R., Sharma, A., Yadav, K. K., Kumar, A., Roy, P., et al. (2013). Pharmacological studies on Buchanania lanzan Spreng.-A focus on wound healing with particular reference to anti-biofilm properties. Asian Pac. J. Trop. Biomed. 3, 967-974. doi: 10.1016/S2221-1691(13)60187-2

Patwardhan, B. (2005). Ethnopharmacology and drug discovery. J. Ethnopharmacol. 100, 50-52. doi: 10.1016/j.jep.2005.06.006

Perry, B. D., and Randolph, T. F. (1999). Improving the assessment of the economic impact of parasitic diseases and of their control in production animals. Vet. Parasitol. 84, 145-168. doi: 10.1016/S0304-4017(99)00040-0

Prashanth, D., Asha, M. K., Amit, A., and Padmaja, R. (2001). Anthelmintic activity of Butea monosperma. Fitoterapia 72, 421-422. doi: 10.1016/S0367-326X(00)00333-6

Prichard, R. (1994). Anthelmintic resistance. Vet. Parasitol. 54, 259-268. doi: 10.1016/0304-4017(94)90094-9

Rashed, K., and Butnariu, M. (2014). Antimicrobial and antioxidant activities of Bauhinia racemosa Lam. and chemical content. Iran J. Pharm. Res. 13, 1073-1080.

Sahoo, S., Panda, P. K., Behera, P. S., Mishra, S. R., and Ellaiah, P. (2008). Antifungal activity of Barringtonia acutangula against selected human pathogenic fungi. Ind. Drugs 45, 26-30.

Sahu, M. C., and Padhy, R. N. (2013). In vitro antibacterial potency of Butea monosperma Lam. against 12 clinically isolated multidrug resistant bacteria Asian Pac. J. Trop. Dis. 3, 217-226. doi:10.1016/S2222-1808(13)60044-4.

Sant, A., Ingole, A., Dhabarde, D., and Kamble, M. (2014). Evaluation of anthelmintic activity of flower extract of Butea monosperma var. lutea. J. Pharmacogn. Phytochem. 2, 152-153.

Saslis-Lagoudakis, C. H., Savolainen, V., Williamson, E. M., Forest, F., Wagstaff, S. J., Baral, S. R., et al. (2012). Phylogenies reveal predictive power of traditional medicine in bioprospecting. Proc. Natl. Acad. Sci. U.S.A. 109, 15835-15840. doi:10.1073/pnas.1202242109

Satpute, K., Bodas, K., Shende, V., Chaus, W., Atul, D., and Amar, G. (2014). Anthelmintic activity of extracts of Holarrhena antidysenterica Wall. World J. Pharma Pharmaceut. Sci. 3, 561-567.

Saxena, H. O., and Brahmam, M. (1994-1996). The Flora of Orissa, Vol. 1-4. Bhubaneswar: RRL; CSIR.

Shruti, S., Goyal, S., Shrivastva, K., Singh, P. M., Dave, K., and Singh, N. (2009). In-vitro anthelmintic activity of hydro alcoholic extract of leaves of Nyctanthes arbortristis Linn. J. Global Pharma Technol. 1, 101-104.

Siddiqui, B. S., Ali, S. T., Rizwani, G. H., Begum, S., Tauseef, S., and Ahmad, A. (2012). Antimicrobial activity of the methanolic bark extract of Holarrhena pubescens (Buch. Ham), its fractions and the pure compound conessine. Nat. Prod. Res. 26, 987-992. doi: 10.1080/14786419.2010.537268

Silhavy, T. J., Kahne, D., and Walker, S. (2010). The bacterial cell envelope. Cold Spring Harb. Perspect Biol. 2: a000414. doi: 10.1101/cshperspect.a000414

Singh, R. K., Singh, K. P., and Turner, N. J. (2013). A special note on Prior Informed Consent (PIC). Why are you asking our gyan (knowledge) and padhati (practice)?: Ethics and prior informed consent for research on traditional knowledge systems. Indian J. Tradit. Knowl. 12, 547-562.

Singh, S. S., and Sharma, S. K. (2013). Anthelmintic potential of stem bark and roots of Alstonia scholaris (L.) R.Br. World J. Pharma Pharmaceut. Sci. 2, 3807-3817.

Soejarto, D. D., Fong, H. H. S., Tan, G. T., Zhang, H. J., Ma, C. Y., Franzblau, S. J., et al. (2005). Ethnobotany/ethnopharmacology and mass bioprospecting: issues on intellectual property and benefit-sharing. J. Ethnopharmacol. 100, 15-22. doi: 10.1016/j.jep.2005.05.031

Suteky, T., and Dwatmadji. (2011). Anthelmintic activity of Melastoma malabatricum extract on Haemonchus contortus activity in vitro. Asian J. Pharm. Clin. Res. 4, 68-70. 
Thatoi, H. N., Panda, S. K., Rath, S. K., and Dutta, S. K. (2008). Antimicrobial activity and ethnomedicinal uses of some medicinal plants from Similipal Biosphere Reserve, Orissa. Asian J. Plant Sci. 7, 260-267. doi: 10.3923/ajps.2008.260.267

Tiwari, P., Jain, R., Kumar, K., Mishra, R., and Chandy, A. (2012). Antibacterial activity and physicochemical evaluation of roots of Butea monosperma. Asian Pacific J. Trop. Biomed. 2, S881-S883. doi: 10.1016/S2221-1691(12)60328-1

Ukil, S., Laskar, S., and Roy, R. N. (2016). Physicochemical characterization and antibacterial activity of the leaf oil of Crotalaria pallida Aiton. J. Taibah Univ. Sci. 10, 490-496. doi: 10.1016/j.jtusci.2015.07.001

Verpoorte, R. (2000). Pharmacognosy in the new millennium: lead finding and biotechnology. J. Pharma Pharmacol. 52, 253-262. doi: 10.1211/0022357001773931

Wagner, H., and Ulrich-Merzenich, G. (2009). Synergy research: approaching a new generation of phytopharmaceuticals. Phytomedicine 16, 97-110. doi: $10.1016 /$ j.phymed.2008.12.018

Wan, H., Moens, M.-F., Luyten, W., Zhou, X., Mei, Q., Liu, L., et al. (2016). Extracting relations from traditional Chinese medicine literature via heterogeneous entity networks. J. Am. Med. Informat. Assoc. 23, 356-365. doi: 10.1093/jamia/ocv092

Williamson, E., Okpako, D. T., and Evans, F. J. (1996). Selection, Preparation and Pharmacological Evaluation of Plant Material. Chichester: John Wiley \& Sons.
Wood-Sheldon,. J., Balick, M. J., and Laird, S. A. (1997). Medicinal Plants: Can Utilization and Conservation Coexist? Bronx, NY: The New York Botanical Garden.

Yadava, R. N., and Tiwari, L. (2005). A potential antiviral flavone glycoside from the seeds of Butea monosperma O. Kuntze. J. Asian Nat. Prod. Res. 7, 185-188. doi: 10.1080/1028602042000204054

Zhu, F., Qin, C., Tao, L., Liu, X., Shi, Z., Ma, X., et al. (2011). Clustered patterns of species origins of nature-derived drugs and clues for future bioprospecting. Proc. Natl. Acad. Sci. U.S.A. 108, 12943-12948. doi: 10.1073/pnas.110 7336108

Conflict of Interest Statement: The authors declare that the research was conducted in the absence of any commercial or financial relationships that could be construed as a potential conflict of interest.

Copyright (C) 2017 Panda, Padhi, Leyssen, Liu, Neyts and Luyten. This is an openaccess article distributed under the terms of the Creative Commons Attribution License (CC BY). The use, distribution or reproduction in other forums is permitted, provided the original author(s) or licensor are credited and that the original publication in this journal is cited, in accordance with accepted academic practice. No use, distribution or reproduction is permitted which does not comply with these terms. 